\title{
"Does the exception prove the rule? - A comparative study of supramolecular synthons in a series of lactam esters"
}

\author{
C. Weck ${ }^{\mathrm{a}}$, E. Nauha ${ }^{\mathrm{b}}$, T. Gruber ${ }^{\mathrm{a}, *}$ \\ a School of Pharmacy, University of Lincoln, Joseph Banks Laboratories, Green Lane, \\ Lincoln LN6 7DL, United Kingdom.E-mail: tgruber@lincoln.ac.uk \\ ${ }^{b}$ School of Chemistry, University of Lincoln, Joseph Banks Laboratories, Green Lane, \\ Lincoln LN6 7DL, United Kingdom.
}




\begin{abstract}
In this paper a series of simple lactam esters and carboxylic acids is studied with respect to their overall conformation and hydrogen bonding patterns. In total, eight lactams featuring $\mathrm{N}_{\alpha^{-}}$ substitution have been synthesized. Additionally, the molecular structures of related lactam esters have been considered. The length of the amide bonds does not seem to be majorly influenced by different substituents unless the electron withdrawing $N$-Boc-protection group is introduced, resulting in a higher susceptibility towards hydrolytic ring opening. As known from other lactams, the $\mathrm{N}_{\alpha}$ ester moiety of the title compounds can be in an axial or equatorial conformation. Smaller ester groups were found to prefer equatorial positions, while larger ones occupy axial sites. $N$-substitution seems to promote axial conformations of the respective $\mathrm{N}_{\alpha}$ group, with enantholactams being the only studied exception. In addition to the two common amide packing motifs, i.e. the $\mathrm{R}_{2}^{2}(8)$ amide dimer $\left(\mathrm{NH}^{\circ} \mathrm{O} / \mathrm{NH} \cdots \mathrm{O}\right)$ and the $\mathrm{C}(4)$ amide chain, a third graph-set was found: the $\mathrm{R}_{2}^{2}(8) \mathrm{NH} \cdots \mathrm{O} / \mathrm{CH} \cdots \mathrm{O}=\mathrm{C}$ heterodimer. In general, there seems to be a tendency for medium-sized lactams as well as lactams with small esters to form $\mathrm{R}_{2}^{2}(8)$ amide dimers. Larger esters and enantholactam esters lead to $\mathrm{C}(4)$ amide chains. In this respect the formation of $\mathrm{R}_{2}^{2}(8) \mathrm{N}-\mathrm{H} \cdots \mathrm{O} / \mathrm{C}-\mathrm{H} \cdots \mathrm{O}=\mathrm{C}$ heterodimers should be seen as a remarkable exception.
\end{abstract}

Keywords:

Lactam synthesis

Hydrolytic lability

Hydrogen bonding synthon

Reactive conformation

Conglomerate 


\section{INTRODUCTION}

Lactams, i.e. cyclic amides, are a prominent class of heterocycles and can be considered as oxo derivatives of the respective cyclic amines. However, their trivial names are used much more commonly (Figure 1). For many years lactams have widely been employed in industry ${ }^{1,2}$ and in the synthesis of more advanced compounds.3-6 Moreover, lactams occur in natural products chemistry ${ }^{7,8}$ and are deployed as final APIs with the $\beta$-lactam antibiotics as the most prominent example. ${ }^{9}$ Despite being first described over one century ago, research on physical and chemical properties of lactams is still highly rewarding. Studies on their reactivity, thermodynamic and kinetic stability and their conformational behavior contribute not only to chemistry, though also to adjacent disciplines like material science and biology. A typical characteristic of lactams is the existence of cis and trans forms resulting from different dihedral angles of the amide bond. ${ }^{10}$ As observed for open amides, lactams also possess partial C-N double bond character, which goes in hand with resonance stabilization. While the amide bond lengths for small and medium-sized lactams (ring sizes 4-9) are rather consistent, ${ }^{11}$ their hydrolytic stability is not with the four and six membered rings being hydrolyzed significantly faster. $^{12}$

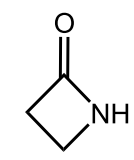

$\beta$-Propiolactam
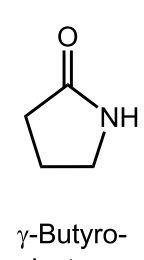
lactam<smiles>O=C1CCCCN1</smiles>

$\delta$-Valerolactam
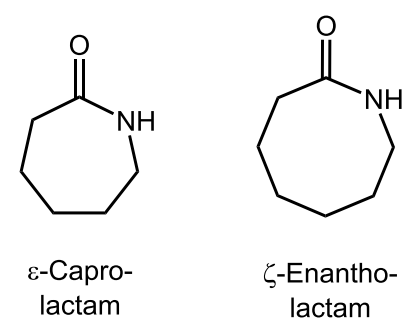

Figure 1. Nomenclature of small and medium sized lactams (trivial names).

Comparative studies on monocyclic lactams and especially simply substituted derivatives are unsatisfyingly rare. ${ }^{13-18}$ As part of our ongoing studies on bridged lactams ${ }^{19}$ we became interested in a series of small and medium-sized lactams featuring a carboxylic acid or a respective ester in the $\mathrm{N}_{\alpha}$ position. In detail we discuss here the synthesis and the X-ray structures of pyroglutamates $\mathbf{1}$ (iso-propylester) and $\mathbf{2}$ (tert-butylester), pyrohomoglutamic acid methyl ester (3) and its respective acid (4), the $\mathrm{N}_{\alpha}$ disubstituted caprolactam ${ }^{20-25} \mathbf{5}$ and the three enantholactam ${ }^{26,27}$ esters 6-8 (Figure 2); additionally, we deliver full analytical characterization. Some of the title compounds are already known as useful building blocks and/or are part of biologically active compounds, such as pyroglutamic acid, ${ }^{28,29}$ iso-propyl pyroglutamate (1) ${ }^{30-32}$ tert-butyl pyroglutamate $(\mathbf{2})^{33-37}$ and pyrohomoglutamic acid $(\mathbf{4})^{38,39}$ and enantholactam 7.40 
<smiles>[R]OC(=O)C1CCC(=O)N1</smiles><smiles>[R]C1CCCC(=O)N1</smiles>

1: $\mathrm{R}={ }^{\text {iso }} \mathrm{Pr}$

2: $\mathrm{R}={ }^{\text {tert } \mathrm{Bu}}$<smiles>CCOC(=O)C1(C)CCCCC(=O)N1</smiles>

5<smiles>[R]OC(=O)C1CCCCCC(=O)N1[R]</smiles>

6: $R^{1}=M e, R^{2}=H$

7: $R^{1}=E t, R^{2}=H$

8: $R^{1}=E t, R^{2}=B o c$

Figure 2. Title compounds 1-8.

The aim of this study was to learn how the ring size of the respective lactam and the nature of the carboxyl pendant affect the overall conformation and the hydrogen bonding pattern in the crystal packing. In general, $\mathrm{R}_{2}^{2}(8)$ amide dimers and $\mathrm{C}(4)$ chains are typical graph-set descriptors found in lactam structures. However, for some title compounds we found alternative supramolecular synthons. For comparison reasons, we also included the molecular structures of related lactam derivatives in our considerations. As a result, we are able to present a comprehensive study on the solid state behavior of this synthetically useful type of compound and discuss the general influence of ring size and substitution pattern on the $\mathrm{COOH}$ and COOR moieties at the $\mathrm{N}_{\alpha}$ position of lactams. The respective moieties can either adopt an axial or an equatorial site, which is of crucial importance for their reactivity e.g. in transannular cyclization reactions. ${ }^{19,41,42}$ For steric reasons only ester groups in axial positions will allow such conversions (Figure 3). Despite the axial and the equatorial conformation are connected via equilibrium in solution, the molecular structures of the title compounds deliver valuable insights into their reactive conformation and give most beneficial information on distances and interactions in and between the molecules.

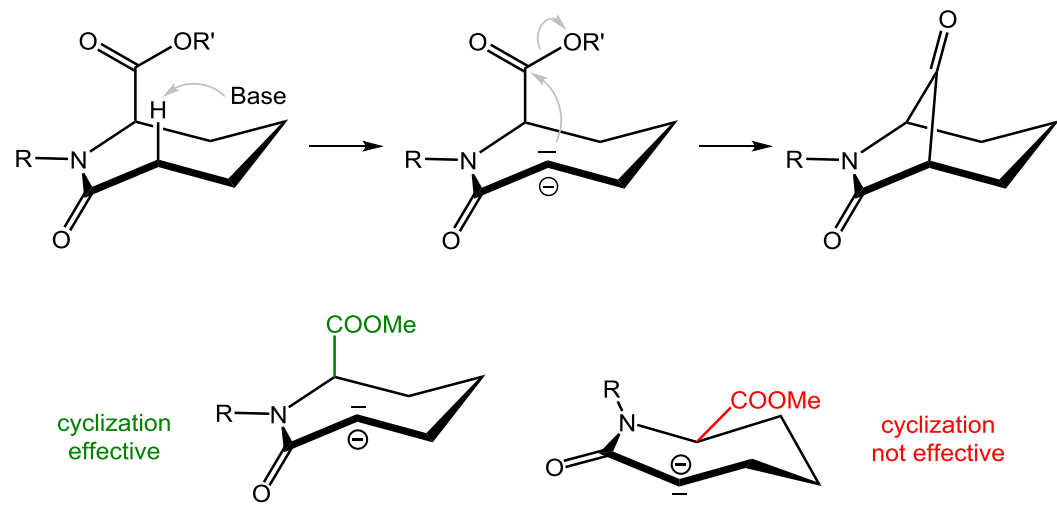

Figure 3. Dieckmann reaction of caprolactam esters as a reported example of a tranns annular cyclization. ${ }^{19}$

\section{EXPERIMENTAL SECTION}

Synthesis of lactams 1-8. Butyrolactams 1 and 2 were synthesized from pyroglutamic acid and the respective alcohol via Steglich esterification. By way of interest, the iso-propyl ester could be isolated in a much higher yield than the respective tert-butyl ester (68\% vs. $9 \%$ ). The respective methyl ester (3) was prepared by direct cyclization of 2-aminoadipic acid in methanol and thionylchloride (58\% yield); saponification resulted in lactam acid 5 (79\%) (Scheme 1a). Title compounds 5-7 were synthesized via Schmidt rearrangement ${ }^{43,44}$ from the 
respective cycloketones $(\mathbf{9 - 1 1})^{45-48}$ in moderate to good yields $(35-72 \%)$ (Scheme 1 b). $N$-Bocprotection of ethyl ester 7 gave enantholactam 8 in $83 \%$ yield. When we tried to saponify the Boc-protected caprolactam $12^{49}$ using $\mathrm{LiOH} / \mathrm{H}_{2} \mathrm{O}_{2}$, ring opening was observed and the respective Boc-protected adipic acid $\mathbf{1 3}$ could be recovered (Scheme 1c).

Scheme 1. (a) Syntheses of Valerolactams 3 and 4. (b) Syntheses of Lactams 5-7 via Schmidt reaction. (c) Hydrolysis of Boc-protected caprolactam 12. ${ }^{\mathrm{a}}$

(a)

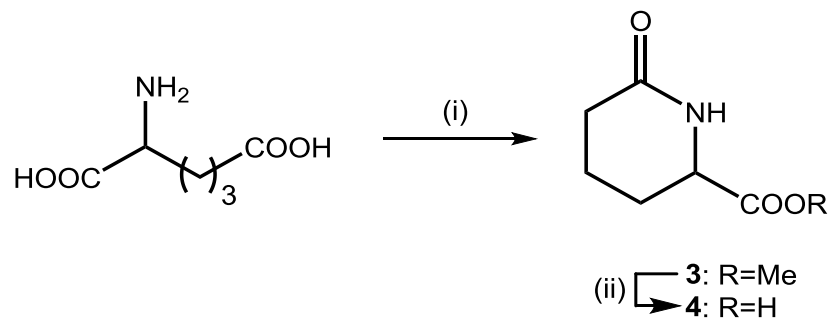

(b)

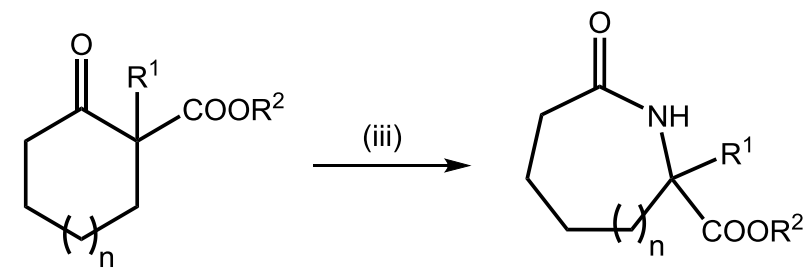

$$
\begin{array}{rl}
\text { 9: } n=1, R^{1}=M e, R^{2}=E t & 5: n=1, R^{1}=M e, R^{2}=E t \\
\text { 10: } n=2, R^{1}=H, R^{2}=M e & 6: n=2, R^{1}=H, R^{2}=M e \\
\text { 11: } n=2, R^{1}=H, R^{2}=E t & 7: n=2, R^{1}=H, R^{2}=E t
\end{array}
$$

(c)

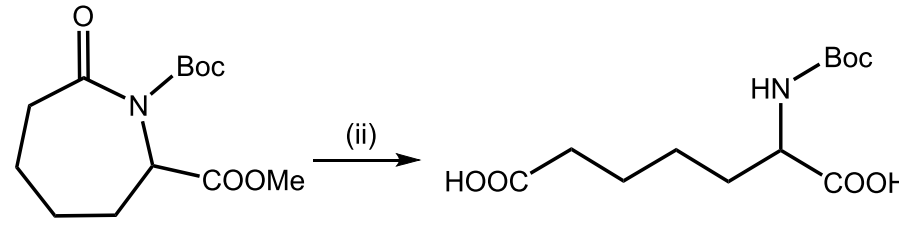

12

Materials and methods. Melting points were determined on a Zeiss Axio Vision microscope fitted with a Linkam THMS600 stage. Infrared spectra were recorded on a PerkinElmer Spectrum 100 FT-IR spectrometer. All wave numbers are given in $\mathrm{cm}^{-1}$. Mass spectra were recorded on a TSQ Endura Mass Spectrometer. High-resolution mass spectra were recorded on a Thermo Exactive Plus Orbitrap Mass Spectrometer with a Dionex UltiMate 3000 Quaternary RSLCnano System. Proton $\left({ }^{1} \mathrm{H}, 500 \mathrm{MHz}\right)$ and carbon $\left({ }^{13} \mathrm{C}, 125 \mathrm{MHz}\right)$ nuclear magnetic resonance experiments were performed on a Bruker Avance 500. NMR samples were prepared in $\mathrm{CDCl}_{3}$ and $\mathrm{MeOD}-\mathrm{d}_{4}$ using TMS as an internal chemical shift standard. Reactions were followed with TLC $(254 \mu \mathrm{m} \mathrm{SiO} 260-\mathrm{F})$, visualization accomplished by $\mathrm{KMnO}_{4}$-staining. Column chromatography was performed on 230-400 mesh, 0.063-0.040 mm). 
All reactions that required water free reaction conditions were performed under a nitrogen atmosphere. Dry solvents were purified over activated aluminum oxide. Commercially available starting materials were used as received by Fluorochem. Ethyl 1-methyl-2cyclohexanonecarboxylate (9) was synthesized from ethyl 2-cyclohexanone-carboxylate, methyl iodide and potassium carbonate according to a literature procedure. ${ }^{45} \mathrm{Methyl}^{47}$ (10) and ethyl 7-cycloheptanonecarboxylate ${ }^{48}$ (11) were synthesized from cycloheptanone using the respective dialkylcarbonate and sodium hydride. The synthesis of caprolactam ester $\mathbf{1 2}$ has been described earlier. ${ }^{19}$

Preparation of pyroglutamates 1 and 2 (Steglich esterification). Commercially available pyroglutamic acid (1 eq.) was dissolved in dry $\mathrm{CH}_{2} \mathrm{Cl}_{2}(10 \mathrm{ml})$ followed by the addition of 4dimethylaminopyridine (DMAP, $100 \mathrm{mg}, 0.82 \mathrm{mmol}$ ) and the respective alcohol (4 eq.). The mixture was cooled to $0{ }^{\circ} \mathrm{C}$ and $N, N^{\prime}$-dicyclohexy lcarbodiimide (DCC, $1.6 \mathrm{~g}, 7.75 \mathrm{mmol}$ ) were added. The mixture was stirred for $24 \mathrm{~h}$. The resulting suspension was filtered and the filtrate washed with $0.5 \mathrm{M}$ hydrochloric acid. The organic layer was dried over $\mathrm{MgSO}_{4}$, concentrated in vacuo and purified by column chromatography (cyclohexane : EtOAc $=2: 1$ ) to give the desired esters.

(RS)-iso-Propyl pyroglutamate (1). Synthesized using $1.0 \mathrm{~g}$ of the starting material. Yield: $900 \mathrm{mg}$ (5.26 mmol, $68 \%$ ); white crystalline solid. TLC: $\mathrm{R}_{f}=0.31$ (EtOAc). $\mathrm{Mp}=86{ }^{\circ} \mathrm{C}$.

$(R S)$-tert-Butyl pyroglutamate (2). Synthesized using $1.0 \mathrm{~g}$ of the starting material. Yield: 119 mg $(0.64 \mathrm{mmol}, 9 \%)$; white crystalline solid. TLC: $\mathrm{R}_{f}=0.26$ (EtOAc). $\mathrm{Mp}=97{ }^{\circ} \mathrm{C}$; lit. ${ }^{50}: 93$ ${ }^{\circ} \mathrm{C}$ (ether/petrolether).

Full analytical data of the respective $(S)$-enantiomers of $\mathbf{1}$ and $\mathbf{2}$ can be found in the literature. ${ }^{51}$

(RS)-Methyl 6-oxo-piperidinecarboxylate (3). Methanol $(40 \mathrm{ml})$ was cooled to $-10{ }^{\circ} \mathrm{C}$ before adding thionylchloride $(3.4 \mathrm{ml}, 17.4 \mathrm{mmol})$, followed by the addition of commercially available 2-aminoadipic acid $(1.00 \mathrm{~g}, 6.88 \mathrm{mmol})$. The resulting mixture was stirred overnight, the solvent removed in vacuo and the residue dissolved in saturated aq. $\mathrm{NaHCO}_{3}$. The aqueous phase was extracted three times with ethyl acetate, dried over $\mathrm{MgSO}_{4}$ and the solvent removed in vacuo to give the desired product as a viscous oil, which crystallized after several days at room temperature. Yield: $572 \mathrm{mg}(4.00 \mathrm{mmol}, 58 \%)$; white crystalline solid. TLC: $\mathrm{R}_{f}=0.23$ (EtAOc). $\mathrm{Mp}=65^{\circ} \mathrm{C}$. Full analytical data of the $(S)$-enantiomer of $\mathbf{3}$ can be found in the literature. ${ }^{52}$

(RS)-6-Oxopiperidinecarboxylic acid (4). Methyl ester 3 (300 $\mathrm{mg}, 1.91 \mathrm{mmol}$ ) was dissolved in a mixture of THF $(15 \mathrm{ml})$ and water $(15 \mathrm{ml})$. Subsequently, LiOH $(183 \mathrm{mg}, 7.64$ mmol) was added, followed by $\mathrm{H}_{2} \mathrm{O}_{2}(30 \%$ in water, $65 \mu \mathrm{l}, 2.10 \mathrm{mmol})$. The mixture was stirred for $24 \mathrm{~h}$, then the $\mathrm{pH}$ adjusted to 3 with $0.5 \mathrm{M}$ hydrochloric acid and extracted three times with ethyl acetate. The combined organic layers were dried over $\mathrm{MgSO}_{4}$ and the solvent was removed in vacuo to give a viscous, colorless oil, which crystallized after several hours to a crystalline product. Yield: $217 \mathrm{mg}(1.52 \mathrm{mmol}, 79 \%) . \mathrm{Mp}=178{ }^{\circ} \mathrm{C}$; lit. ${ }^{53}: 178-179{ }^{\circ} \mathrm{C} .{ }^{1} \mathrm{H}$ NMR: (500 MHz, MeOD-d 4 ) $\delta 3.99\left(\mathrm{t},{ }^{3} J=6.3 \mathrm{~Hz}, 1 \mathrm{H}, H 1\right), 2.40\left(\mathrm{t},{ }^{3} J=7.2 \mathrm{~Hz}, 2 \mathrm{H}, H 4\right)$, 2.05-1.89 (m, 2H, H3, H2), 1.85-1.67 (m, 2H, H3',H2'). ${ }^{13} \mathrm{C}$ NMR: (125 MHz, MeOD-d 4$) \delta$ 175.1 (C5), 170.1 (C6), 52.3 (C1), 32.6 (C4), 29.5 (C2), 20.0 (C3). IR (ATR) $v_{\max }: 3202$ $(C O N H) ; 2933$ (CH-aliphatic); $1720(C=O$, ester $) ; 1642(C=O$, lactam $) ; 1582 ; 1489 ; 1453$; $1408 ; 1372 ; 1329 ; 1297 ; 1246 ; 1222 ; 1172 ; 1098 ; 1036 ; 940 ; 873 ; 799 ; 765 ; 737 ; 710 ; 620$; 538; 495. HR-MS: calculated $144.0655 \mathrm{~g} / \mathrm{mol}[\mathrm{MH}]^{+}$, found $144.0643 \mathrm{~g} / \mathrm{mol}$.

General synthetic procedure for the synthesis of lactams 5-7 (Schmidt reaction). The respective ketone (1 eq.) was dissolved in $\mathrm{CHCl}_{3}(30 \mathrm{ml})$, followed by the addition of concentrated $\mathrm{H}_{2} \mathrm{SO}_{4}(15 \mathrm{ml})$. Finally, sodium azide (1.2 eq.) was added carefully. The mixt ure was then stirred gently and heated to $50{ }^{\circ} \mathrm{C}$ for $6 \mathrm{~h}$. The cooled mixture was poured on crushed ice $(200 \mathrm{~g})$ and concentrated aq. $\mathrm{NH}_{3}$ was added until the aqueous phase reacted basic. The 
layers were separated and the aqueous layer was washed three times with $\mathrm{CHCl}_{3}$. The combined organic layers were dried over $\mathrm{MgSO}_{4}$, the solvent was removed in vacuo and the residue was purified using column chromatography $\left[\mathrm{SiO}_{2}\right.$; ethyl acetate] to give the desired lactams 5-7.

Ethyl 2-methyl-7-oxoazepanecarboxylate (5). Synthesized using $1.40 \mathrm{~g}$ ethyl 1-methyl-2cyclohexanonecarboxylate (9) as starting material. Yield: $1.12 \mathrm{~g}(5.62 \mathrm{mmol}, 74 \%)$; off-white crystalline solid. TLC: $\mathrm{R}_{f}=0.28$ (EtOAc). $\mathrm{Mp}=96.0^{\circ} \mathrm{C} .{ }^{1} \mathrm{H} \mathrm{NMR}:\left(500 \mathrm{MHz}, \mathrm{CDCl}_{3}\right) \delta 6.13$ (br s, $1 \mathrm{H}, N H) ; 4.25$ (q, $\left.{ }^{3} J=7.1 \mathrm{~Hz}, 2 \mathrm{H}, H 9\right) ; 2.55-2.50(\mathrm{~m}, 1 \mathrm{H}, H 3) ; 2.37-2.26(\mathrm{~m}, 2 \mathrm{H}, H 6$, $\left.H 3^{\prime}\right) ; 1.92-1.87$ (m, 1H, H4); 1.76-1.68 (m, 2H, H6' $H 5$ ); 1.61-1.54 (m, 2H, H4', H5'); 1.49 (s, $3 \mathrm{H}, H 11) ; 1.31$ (t, $\left.\left.{ }^{3} J=7.1 \mathrm{~Hz}, 3 \mathrm{H}, H 10\right) .{ }^{13} \mathrm{C} \mathrm{NMR:} \mathrm{(125} \mathrm{MHz,} \mathrm{CDCl}_{3}, \delta[\mathrm{ppm}]\right) 177.6(C 2)$; 173.8 (C8); 61.8 (C9); 59.7 (C7); 39.1 (C6); 37.6 (C3); 28.3 (C11); 26.4 (C5); 22.9 (C5); 14.2 (Cl0). IR (ATR) v $\max : 3198$ (CONH); 3087 (CONH); 2974 (CH-aliphatic); 2936 (CHaliphatic); 2859 (CH-aliphatic); 1730 ( $C=O$ ester); 1661 ( $C=O$ lactam); 1579; 1456; 1411; $1382 ; 1360 ; 1343 ; 1311 ; 1290 ; 1261 ; 1215 ; 1174 ; 1152 ; 1121 ; 1093 ; 1057 ; 1038 ; 1006 ; 954$; $889 ; 879 ; 837 ; 803 ; 769 ; 757 ; 735 ; 718 ; 693 ; 656 ; 620 ; 576 ; 547 ; 510 ; 462$. HR-MS: calculated $200.1286 \mathrm{~g} / \mathrm{mol}[\mathrm{M}+\mathrm{H}]^{+}$, found $200.1264 \mathrm{~g} / \mathrm{mol}$.

Methyl 8-oxoazocanecarboxylate (6). Synthesized using 1.0 g methyl 2-cycloheptano necarboxylate (10) as starting material. Yield: $442 \mathrm{mg}(2.39 \mathrm{mmol}, 35 \%)$; off-white crystalline solid. TLC: $\mathrm{R}_{f}=0.37$ (EtOAc). $\mathrm{Mp}=89{ }^{\circ} \mathrm{C}$; lit. ${ }^{54}: 80-82{ }^{\circ} \mathrm{C} .{ }^{1} \mathrm{H}$ NMR: $\left(500 \mathrm{MHz}, \mathrm{CDCl}_{3}, \delta\right.$ [ppm]) 6.05 (br d, $1 \mathrm{H}, N H) ; 4.31-4.26$ (m, 1H, H8); 3.79 (s, 3H, H1O); 2.44-2.35 (m, 2H, H3, $\left.H 3^{\prime}\right)$; 2.05-1.99 (m, 1H, H7); 1.92-1.72 (m, 4H, H5, H6, H4, H4'); 1.68-1.61 (m, $\left.1 \mathrm{H}, H 7^{\prime}\right)$; 1.57-1.42 (m, 2H, H5',H6'). ${ }^{13} \mathrm{C}-\mathrm{NMR}$ (125 MHz, $\left.\mathrm{CDCl}_{3}, \delta[\mathrm{ppm}]\right) 175.3$ (C2); 172.1 (C9); 54.9 (C10); 52.7 (C8); $36.2(C 3) ; 33.6(C 7) ; 27.9(C 4)$; 25.8 (C5); 24.2 (C6), IR (ATR) $v_{\max }$ : 3365 (CONH); 2922 (CH-aliphatic); 2856 ( $\mathrm{CH}$-aliphatic); 1732 ( $\mathrm{C}=\mathrm{O}$ ester $) ; 1650(\mathrm{C}=\mathrm{O}$ lactam); 1488; 1429; 1397; 1362; 1334; 1309; 1256; 1216; 1158; 1030; 981; 951; 911; 887; $873 ; 822 ; 791 ; 765 ; 747 ; 720 ; 677 ; 638 ; 570 ; 516$. HR-MS: calculated $186.1130 \mathrm{~g} / \mathrm{mol}[\mathrm{M}+\mathrm{H}]^{+}$, found $186.1110 \mathrm{~g} / \mathrm{mol}$.

Ethyl 8-oxoazocanecarboxylate (7). Synthesized using $1.0 \mathrm{~g}$ ethyl 2-cycloheptanonecarboxylate (11) as starting material. Yield: $627 \mathrm{mg}$ (3.15 mmol, $54 \%)$; viscous, colorless oil, which slowly crystallizes. $\mathrm{R}_{f}=0.23$ (EtOAc). $\mathrm{Mp}=91{ }^{\circ} \mathrm{C}$; lit. ${ }^{55}$ : 96-98 ${ }^{\circ} \mathrm{C}$. ${ }^{1} \mathrm{H}$ NMR: $(500$ $\left.\mathrm{MHz}, \mathrm{CDCl}_{3}\right) \delta 6.02$ (br d, $\left.1 \mathrm{H}, N H\right) ; 4.28-4.22$ (m, 3H, H1, H9); 2.4-2.38 (m, 2H, H6, H6'); 2.02-2.00 (m, $1 \mathrm{H}, H 2) ; 1.88-1.75$ (m, 4H, $\left.H 3, H 4, H 5, H 5^{\prime}\right) ; 1.64-1.47$ (m, 3H, $H 4^{\prime}, H 3^{\prime}, H 2^{\prime}$ ), $1.30\left(\mathrm{t},{ }^{3} \mathrm{~J}=7.2 \mathrm{~Hz}, 3 \mathrm{H}, \mathrm{H1O}\right),{ }^{13} \mathrm{C}$ NMR: $\left(125 \mathrm{MHz}, \mathrm{CDCl}_{3}\right) \delta 175.3$ (C7); $171.6(C 8) ; 61.9$ (C9); 55.0 (C1); 36.3 (C6); 33.6 (C2); 27.9 (C5); 25.8 (C3); 14.1 (C10) IR (ATR) 3311 (CONH); 2937 (CH-aliphatic); 2867 (CH-aliphatic); 1730 ( $C=O$ ester); 1614 ( $C=O$ lactam); $1467 ; 1447 ; 1362 ; 1350 ; 1322 ; 1289 ; 1260 ; 1242 ; 1221 ; 1184 ; 1160 ; 1095 ; 1061 ; 1017 ; 947$; $915 ; 800 ; 770 ; 753 ; 713 ; 654 ; 572 ; 513 ; 502$, HR-MS: calculated $200.1281 \mathrm{~g} / \mathrm{mol}[\mathrm{M}+\mathrm{H}]^{+}$, found $200.1281 \mathrm{~g} / \mathrm{mol}$.

1-tert-Butyl 2-ethyl 8-oxoazocane-1,2-dicarboxylate (8). Enantholactam $7(2.00 \mathrm{~g} 10$ mmol) was dissolved in dry toluene $(50 \mathrm{ml})$. DMAP $(200 \mathrm{mg}, 1.64 \mathrm{mmol}), \mathrm{Boc}_{2} \mathrm{O}(6.55 \mathrm{~g}, 30$ mmol) and $N, N$-diisopropylethylamine (DIPEA, $2.44 \mathrm{ml}, 14 \mathrm{mmol}$ ) were added before the mixture was refluxed for $6 \mathrm{~h}$. Subsequently, the reaction was quenched with water $(15 \mathrm{ml})$. The layers were separated and the aqueous layer was extracted three times with toluene. The combined organic layers were dried over $\mathrm{MgSO}_{4}$, the solvent was removed in vacuo and the residue was purified using column chromatography [cyclohexane : EtOAc, $4: 1$ ] to give a yellow viscous oil, which crystallized after several days. Yield: $2.47 \mathrm{~g}(8.25 \mathrm{mmol}, 83 \%)$. $\mathrm{R}_{f}$ $=0.16($ cyclohexane $:$ EtOAc $=1: 4) . \mathrm{Mp}=98{ }^{\circ} \mathrm{C} .{ }^{1} \mathrm{H}$ NMR: $\left(500 \mathrm{MHz}, \mathrm{CDCl}_{3}\right) \delta 4.58(\mathrm{dd}$, $\left.J_{d}=4.5 \mathrm{~Hz}, J_{d d}=12.3 \mathrm{~Hz}, 1 \mathrm{H}, H 1\right) ; 4.21\left(\mathrm{qq},{ }^{2} J_{q}=7.1 \mathrm{~Hz} ;{ }^{3} J_{q q}=21.3 \mathrm{~Hz} ; 2 \mathrm{H}, H 9\right) ; 2.79-2.73$ (m, $1 \mathrm{H}, H 6) ; 2.58-2.53\left(\mathrm{~m}, 1 \mathrm{H}, H 6^{\prime}\right) ; 2.25-2.18(\mathrm{~m}, 1 \mathrm{H}, H 2) ; 2.08-2.00(\mathrm{~m}, 1 \mathrm{H}, H 2) ; 1.96-1.90$ (m, 1H, H5); 1.83-1.67 (m, 3H, H5', H4, H3); 1.51 (s, 9H, H13, H14, H15); 1.45-1.37 (m, 2H, 
$\left.\left.H 4^{\prime}, H 3^{\prime}\right) ; 1.28\left(\mathrm{t},{ }^{3} \mathrm{~J}=7.1 \mathrm{~Hz}, 3 \mathrm{H}, H 10\right),{ }^{13} \mathrm{C} \mathrm{NMR:} \mathrm{(125} \mathrm{MHz,} \mathrm{CDCl}_{3}\right) \delta 177.0(C 7) ; 170.3$ (C8); 151.9 (C11); 83.4 (C12); 61.5 (C9); 58.3 (C1); 38.1 (C6); 30.8 (C2); 29.1 (C5); 28.0 (C13, C14, C15); 27.1 (C4); 24.2 (C3); 14.1 (C10), IR (ATR): 2980 (CH-aliphatic); 2942 (CHaliphatic); 2865 ( $C H$-aliphatic); 2334; 1745 ( $C=O$ ester $) ; 1713$ ( $C=O$ carbamate $) ; 1699(C=O$ lactam); 1464; 1448; 1394; 1367; 1354; 1331; 1315; 1293; 1279; 1260; 1200; 1149; 1125; 1109; 1083; 1047; 1022; 988; 955; 932; 897; 850; 818; 766; 743; 708; 674; 592; 549; 526; 479, HR-MS: calculated $322.1630 \mathrm{~g} / \mathrm{mol}[\mathrm{M}+\mathrm{Na}]^{+}$, found $322.1623 \mathrm{~g} / \mathrm{mol}$.

2-[[(1,1-dimethylethoxy)carbonyl]amino]heptanedioic acid (13). 1-tert-Butyl 2-methyl 7oxoazepane-1,2-dicarboxylate (1.02 g, $3.57 \mathrm{mmol})$ was dissolved in $25 \mathrm{ml} \mathrm{THF}$, LiOH $(0.34$ g, $14.2 \mathrm{mmol}$ ) dissolved in $25 \mathrm{ml}$ water and $3.5 \mathrm{ml}$ of $\mathrm{H}_{2} \mathrm{O}_{2}$ (30\% in water) were added and the resulting suspension was stirred for $24 \mathrm{~h}$. The $\mathrm{pH}$ was adjust to 3 with $1 \mathrm{M} \mathrm{HCl}$ solution and aqueous solution was extracted three times with EtOAc. The combined organic layers were dried over $\mathrm{MgSO}_{4}$, the solvent was removed in vacuo to give the desired product as a white, crystalline solid. Yield: $0.748 \mathrm{~g}(2.72 \mathrm{mmol}, 78 \%) \mathrm{Mp}=118{ }^{\circ} \mathrm{C}$ (decomposition). ${ }^{1} \mathrm{H} \mathrm{NMR}$ : $\left(500 \mathrm{MHz}, \mathrm{MeOH}-\mathrm{d}_{4}\right) \delta 4.06\left(\mathrm{dd}, J_{d}=4.8 \mathrm{~Hz}, J_{d d}=8.9 \mathrm{~Hz}, 1 \mathrm{H}, H 2\right) ; 2.30\left(\mathrm{t},{ }^{3} J=7.4 \mathrm{~Hz}, 2 \mathrm{H}\right.$, H6); $1.82-1.79$ (m, 1H, H3); $1.65-1.62\left(\mathrm{~m}, 3 \mathrm{H} ; H 5, H 3^{\prime}\right) ; 1.44-1.43\left(\mathrm{~m}, 11 \mathrm{H}, H 4, H 10^{13} \mathrm{C}\right.$ NMR: $176.0(C 1) ; 174.9$ (C7); 156.8 (C8); 80.0 (C9); 53.5 (C2); 33.3; 31.2 (C3, C6); 27.3 (C10); 25.1; 24.2 (C4; C5). IR (ATR) $v_{\max }: 3324$ (CONH); 2976 (CH-aliphatic); 2936 (CHaliphatic); 2859 (CH-aliphatic); 1729 ( $C=O$ ester); 1678 ( $C=O$ lactam); 1645; 1531; 1454; $1395 ; 1368 ; 1298 ; 1280 ; 1254 ; 1215 ; 1159 ; 1106 ; 1068 ; 1051 ; 1014 ; 886 ; 852 ; 819 ; 784 ; 762$; $743 ; 684 ; 626 ; 579 ; 535 ; 459$. HR-MS: calculated $276.1442 \mathrm{~g} / \mathrm{mol}[\mathrm{M}+\mathrm{H}]^{+}$, found 276.1424 $\mathrm{g} / \mathrm{mol}$. Some analytical data of the respective L-enantiomer of $\mathbf{1 3}$ has already been described in the literature. ${ }^{56}$

Structural characterization. Crystals of 1, 2, 5, 6 and 8 suitable for X-ray Diffraction were prepared by slow solvent evaporation of the respective solutions in ethyl acetate $(\mathbf{1}, \mathbf{2}, \mathbf{5}, \mathbf{6})$ or methanol (8). Compounds 3, 4, 7 and 13 were recovered as oils, which produced crystals suitable for X-ray diffraction after several days. Single crystal X-ray diffraction was performed at $173 \mathrm{~K}$ with a Bruker D8 Venture diffractometer using a Cu- $\mathrm{K}_{\alpha}$ source. Structure solution was carried out with shelxs ${ }^{57}$ and structure refinement with shelx ${ }^{57}$ was finished using ShelXle ${ }^{58}$ software. For selected crystallographic and structural refinement parameters, molecular torsion angles and information regarding non-covalent interactions see Tables S1S7, Supporting Information. The crystallographic data for the structures in this paper have been deposited with the Cambridge Crystallographic Data Centre; CCDC numbers: 1839816 (1), 1839824 (2), 1839823 (3), 1839820 (4), 1839817 (5), 1839818 (6), 1839819 (7), 1839821 (8), $1872073(\mathbf{1 3})$.

\section{RESULTS AND DISCUSSION}

Butyrolactams 1 and 2. In this series we synthesized four esters of pyroglutamic acid, viz. methyl, ${ }^{59}$ ethyl, ${ }^{60}$ iso-propyl (1) and tert-butyl (2). The methyl and ethyl ester could only be recovered as oils, while $\mathbf{1}$ and $\mathbf{2}$ could be crystallized, followed by the determination of their $\mathrm{X}$-ray struture. iso-Propylester $\mathbf{1}$ adopts a slight envelope conformation with $\mathrm{C} 2$ deviating from the C4-N1-C1-C2 mean plane by $0.1962(19) \AA$ (Figure 4a); this is quite low compared to the parent lactam $\left(0.371 \AA\right.$ ) (CSD code: NILYAI). ${ }^{61}$ The ester group of $\mathbf{1}$ is in an axial position, though it is debatable if a C4-N1-C1-C5 angle of $-125.58(10)^{\circ}$ justifies the differentiation into axial/equatorial in this specific case.

In the packing, two molecules of 1 related via an inversion center form an $\mathrm{R}_{2}^{2}(8)$ amide dimer via $\mathrm{N}-\mathrm{H} \cdots \mathrm{O}$ hydrogen bonds. These typical arrangements, which are also found in the 
respective parent lactam, are interconnected via $\mathrm{C}-\mathrm{H} \cdots \mathrm{O}$ interactions between $\mathrm{C} 3$ and the carbonyl oxygen featuring the graph set descriptor $\mathrm{R}_{2}^{2}(8)$ (Figure $4 \mathrm{~b}$ ).

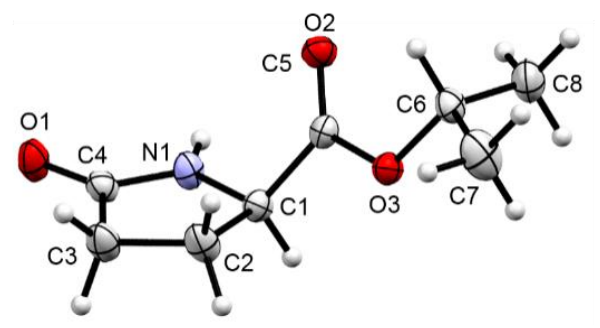

a)

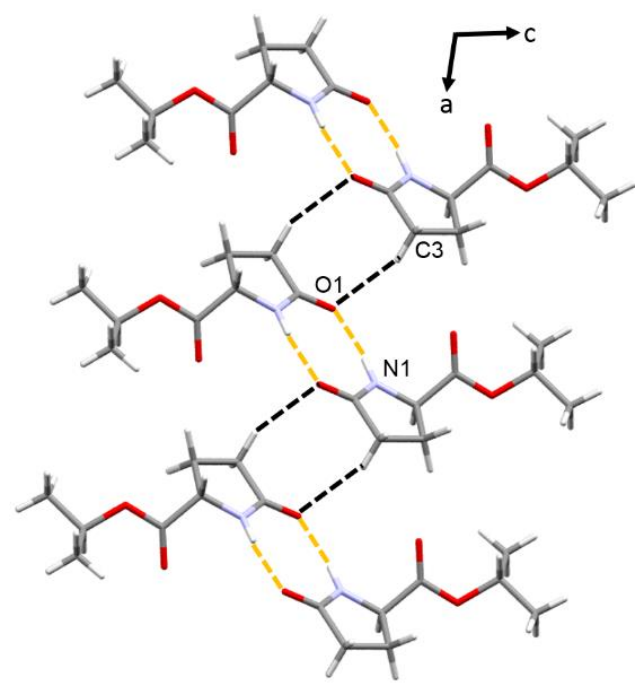

b)

Figure 4. Molecular structure of iso-propyl ester 1 (a) and its packing diagram (b). Hydrogen bonds (orange) and $\mathrm{C}-\mathrm{H} \cdots \mathrm{O}$ contacts (black) are shown as broken lines.

The tert-butyl ester of pyroglutamic (2) crystallizes in the monoclinic space group; an orthorhombic polymorph of $\mathbf{2}$ has been described earlier (CSD code: DICXET). ${ }^{62}$ The asymmetric unit of the polymorph described here consists of one molecule in an envelope conformation, which is much more pronounced than those of the isopropyl ester (1). Carbon $\mathrm{C} 2$ deviates by $0.329(3) \AA$ from the $\mathrm{C} 4-\mathrm{N} 1-\mathrm{C} 1-\mathrm{C} 2$ mean plane (Figure 5a); for the orthorhombic polymorph an ever larger bend $(0.412 \AA)$ is observed. The tert-butyl ester groups of 2 adopts an axial position with a C4-N1-C1-C5 angle of -102.50(16) ${ }^{\circ}$, which is comparable to the polymorph $\left(100.4^{\circ}\right)$ (Figure 5b). As expected, the methyl groups of the tert-butyl units avoid an eclipsed conformation with respect to the carbonyl group; this arrangement results in two intramolecular $\mathrm{C}-\mathrm{H} \cdots \mathrm{O}$ contacts.

The packing of tert-butyl ester $\mathbf{2}$ differs significantly from the one of the iso-propyl ester (1) discussed above. In both polymorphs of $\mathbf{2}$, the amide units are engaged in $C(4)$ chains consisting of $\mathrm{N}-\mathrm{H} \cdots \mathrm{O}$ hydrogen bonds; the strength of the interaction is thereby comparable with those of 1 . The $\mathrm{N}-\mathrm{H} \cdots \mathrm{O}$ chains are further connected by two $\mathrm{C}-\mathrm{H} \cdots \mathrm{O}$ contacts involving $\mathrm{C} 1 \cdots \mathrm{O} 1$ and $\mathrm{C} 3 \cdots \mathrm{O} 3$ featuring the graph-set descriptor $\mathrm{R}_{2}^{2}(8)$. The resulting molecular bands are linked to their neighbors via a weaker $\mathrm{C}-\mathrm{H} \cdots \mathrm{O}$ contact. Towards the crystallographic $a$ axis the molecular bands display hydrophobic interactions from the tert-butyl residues giving a layered overall packing (Figure 5c). When comparing the packing of $\mathbf{1}$ and both polymorphs 
of 2 , the $\mathrm{R}_{2}^{2}(8) \mathrm{C}-\mathrm{H} \cdots \mathrm{O}$ dimers occur in all three packing diagrams, despite the generally more dominant amide hydrogen bonding pattern is changing from 1 to 2 (Figure S1, Supporting Information).

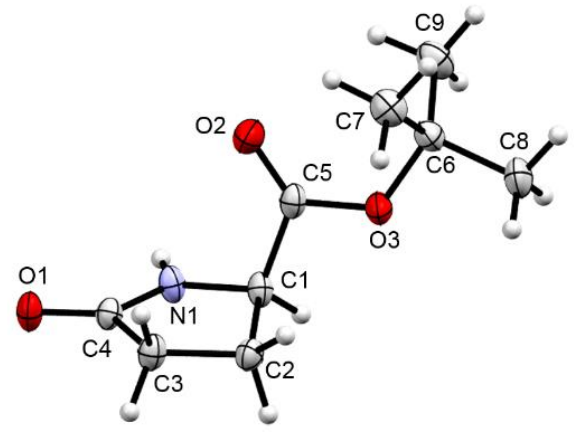

a)

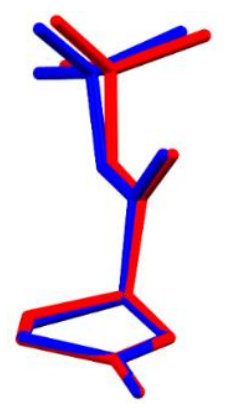

b)

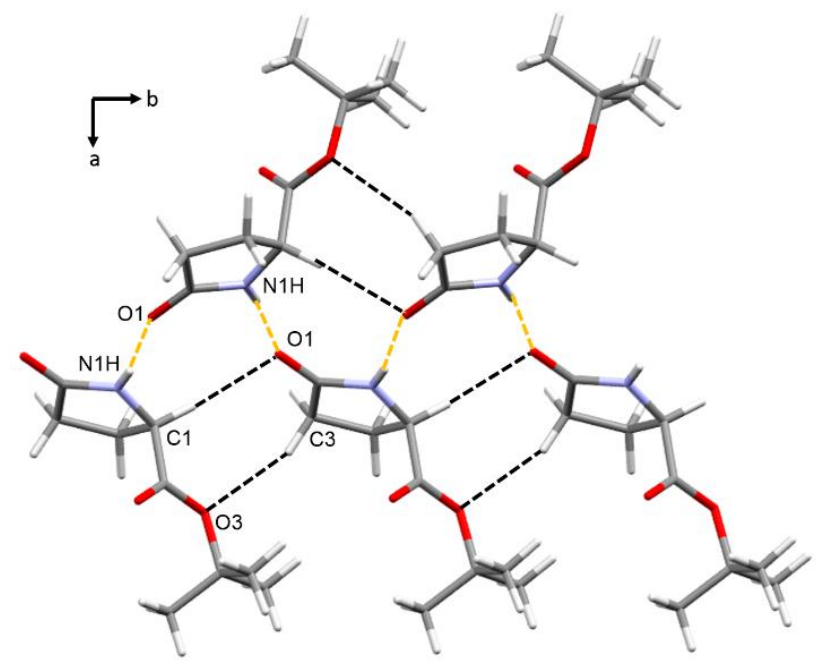

c)

Figure 5. Molecular structure of tert-butyl ester $\mathbf{2}$ in the monoclinic polymorph (a) and the overlay of the $\mathbf{2}$ in the monoclinic (red) and orthorhombic space group (blue) (overlay of amide region) (b). Packing behavior of $\mathbf{2}$ displayed in direction of the $c$ axis.

Valerolactams 3 and 4. The amide region of methyl ester 3 is more or less planar with atoms C2 and C3 deviating from planarity by $0.359(2) \AA$ for C2 and 0.395(2) $\AA$ for C3. The ester moiety is in a clear equatorial position (Figure 6a). As observed for the parent valerolactam (CSD code: HIQJOJ) ${ }^{11}$ two molecules of 5 form an $\mathrm{R}_{2}^{2}(8)$ amide dimer via $\mathrm{N}-\mathrm{H} \cdots \mathrm{O}$ hydrogen bonds (Figure $6 \mathrm{~b}$ ). The dimerized lactams are connected via $\mathrm{C}-\mathrm{H} \cdots \mathrm{O}$ interactions between $\mathrm{C} 4$ and the carbonyl oxygen forming bands in the direction of the $b$ axis. Further interconnection occurs by rather weak $\mathrm{C}-\mathrm{H} \cdots \mathrm{O}$ contacts in the $c$ direction and hydrophobic interactions between the bands (Fig. 6c). 


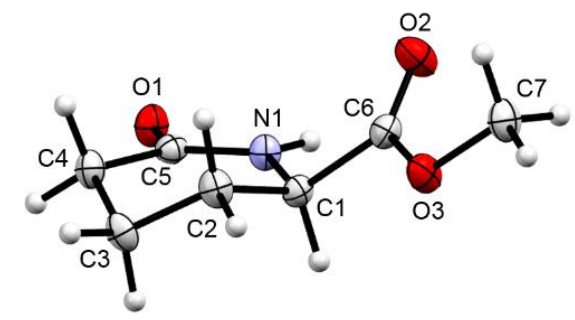

a)

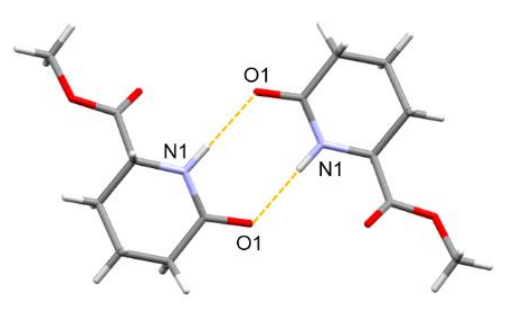

b)

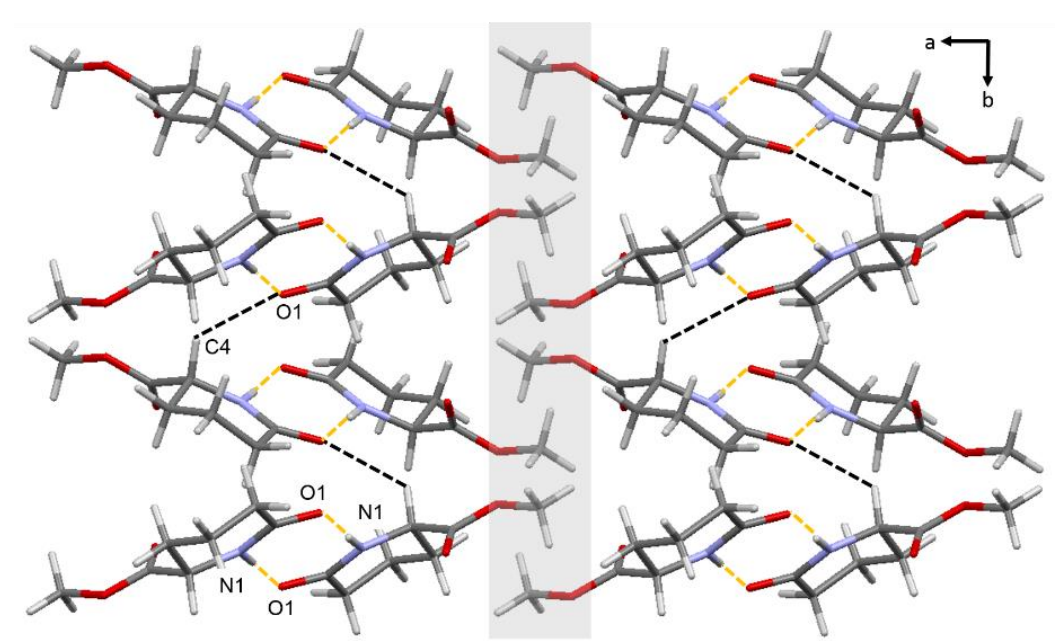

c)

Figure 6. Molecular structure (a) and dimer formation in $\mathbf{3}$ showing the $\mathrm{R}_{2}^{2}(8)$ hydrogen bonding motif (b). When viewing the packing down the $c$ axis a combination of strong $\mathrm{N}-\mathrm{H} \cdots \mathrm{O}$ and weaker $\mathrm{C}-\mathrm{H} \cdots \mathrm{O}$ hydrogen bonds is evident; hydrophobic interactions have been shaded in grey (c).

The conformation of pyrohomoglutamic acid (4), i.e. the $\mathrm{N}_{\alpha}$ carboxylic acid of valerolactam, is very similar to those of the parent compound. The molecule is in the typical half-chair with atoms $\mathrm{C} 2$ and $\mathrm{C} 3$ deviating from the amide mean plane by $0.463(3)$ and $0.278(3) \AA$. The $\mathrm{COOH}$ unit occupies an axial position (Figure 7a). In the packing of $\mathbf{4}$, two main interactions have been found: 1. The carboxylic acid is engaged in $\mathrm{C}(7)$ chains formed by strong $\mathrm{O}-\mathrm{H} \cdots \mathrm{O}$ hydrogen bonding interactions with the amide carbonyl. 2. These chains are interconnected by $\mathrm{R}_{2}^{2}$ (8) amide dimers via $\mathrm{N}-\mathrm{H} \cdots \mathrm{O}$ hydrogen bonds. The latter are rather weak in comparison to those of the other lactams. This is not only expressed by the longer donor-acceptor distance, but also by the low angle of $152.2(16)^{\circ}$. It leads to a displacement of the participating amide regions of $0.872 \AA$ (Figure $7 \mathrm{~b}$ ). In addition to the strong hydrogen bonds, the $\mathrm{O}-\mathrm{H} \cdots \mathrm{O}$ chains are further interconnected by two $\mathrm{C}-\mathrm{H} \cdots \mathrm{O}$ contacts with the graph set descriptor $\mathrm{R}_{2}^{2}(8)$ for $\mathrm{C} 4 \cdots \mathrm{O} 3$ and $\mathrm{R}_{3}^{2}(9)$ for $\mathrm{C} 1 \cdots \mathrm{O} 2$. The formed sheets are linked by two more $\mathrm{C}-\mathrm{H} \cdots \mathrm{O}$ contacts involving $\mathrm{C} 1 \cdots \mathrm{O} 1$ and $\mathrm{C} 2 \cdots \mathrm{O} 3$ (Figure $7 \mathrm{c}$ ). 


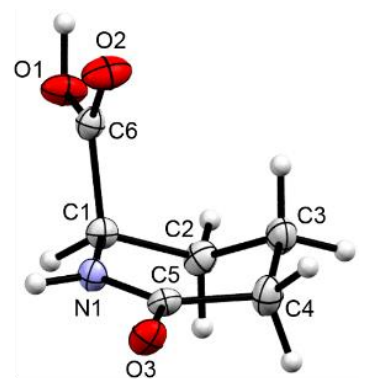

a)

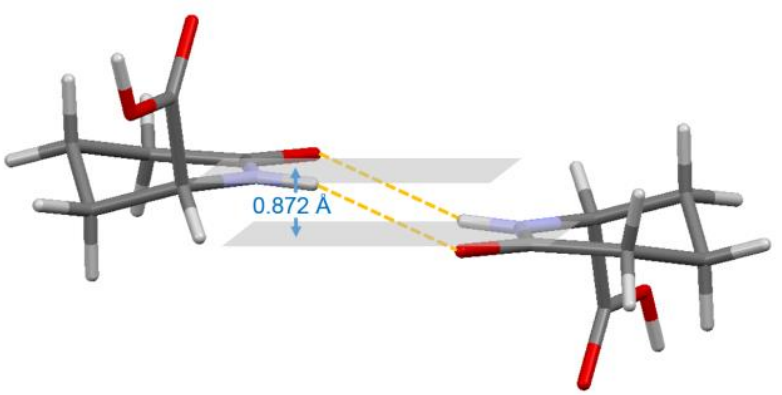

b)

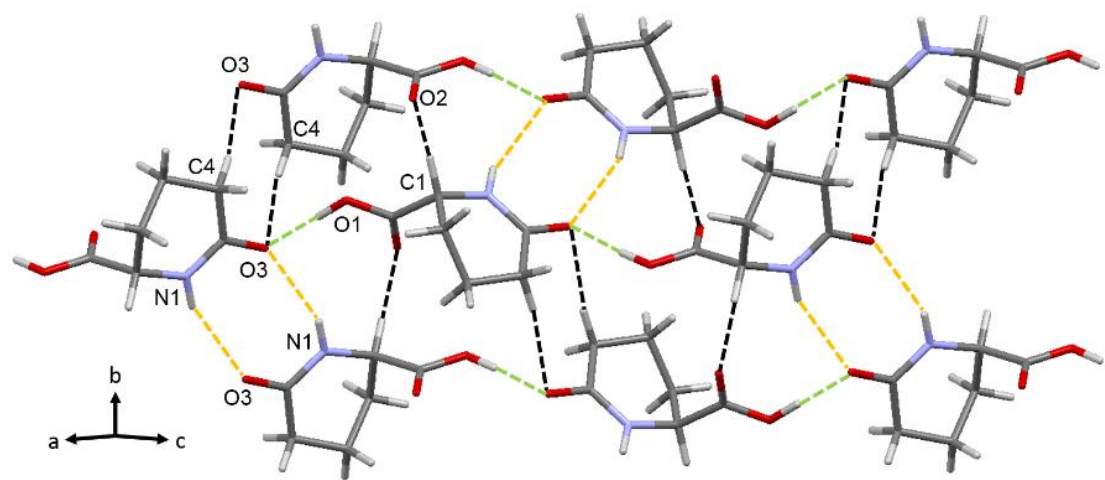

c)

Figure 7. a) Molecular structure of 4. b) Formation of displaced $\mathrm{R}_{2}^{2}(8)$ dimers in 4. c) Packing diagram featuring a combination of $\mathrm{NH}^{\cdots} \mathrm{O}$ and $\mathrm{OH} \cdots \mathrm{O}$ hydrogen bonds.

The $\mathrm{C}(7)$ graph set descriptor featuring $\mathrm{O}-\mathrm{H} \cdots \mathrm{O}$ hydrogen bonds seems to be a rather dominating interaction for other pyrohomoglutamic acids and is also found in respective $\mathrm{N}$ alkylated species (CSD codes: WALWOY, ${ }^{63}$ LOQCOL, $^{64}{ }^{4} \mathrm{CQCUR}^{64}$ ). Even the loss of the amide proton does not change the strength of $\mathrm{O}-\mathrm{H} \cdots \mathrm{O}$ hydrogen bonds significantly $(2.574-$ $2.560 \AA$ ).

Caprolactam 5. The conformational behavior of caprolactams is closely related to those of cycloheptene ${ }^{65}$, existing in a symmetrical (pseudo) chair, a symmetrical boat, a twist-boat and a biplanar form ${ }^{66}$, with the chair being lowest in energy. Caprolactam 5 occupies a chair and its conformation is only slightly deviating from the one known for the parent caprolactam (CSD code: CAPLAC ${ }^{67}$ ). The largest difference is observed for the C6-N1-C1-C2 torsion angle $\left[59.3(2)^{\circ}\right.$ vs. $\left.67.8^{\circ}\right]$ (Figure 8a). The additional $\mathrm{N}_{\alpha}$ methyl group in $\mathbf{5}$ has also no significant influence on the amide bond length compared with the caprolactam methyl ester (CSD code: BOLHER $^{49}$ ).

In 5 , the ester pendant occupies an axial position. In the packing, $R_{2}^{2}(8)$ amide dimers connected via $\mathrm{N}-\mathrm{H} \cdots \mathrm{O}$ hydrogen bonds can be found (Figure $8 \mathrm{~b}$ ). By way of interest, the position of the ester supersedes its size in terms of direct influence on $\mathrm{H}$ bonding strength. With the ester moiety in an axial conformation such as in $\mathbf{5}$ or the monodesaturated methyl ester (CSD code: BOLJIX $^{49}$ ) the $\mathrm{N}-\mathrm{H} \cdots \mathrm{O}$ distances are comparable to those in the parent caprolactam. For the caprolactam methyl ester (BOLHER) featuring an equatorial ester unit the dimerizing hydrogen bonds are significantly weaker. In the packing the lactam dimers are engaged in a series of $\mathrm{C}-\mathrm{H} \cdots \mathrm{O}$ contacts involving $\mathrm{C} 2$ and $\mathrm{C} 5$ and all three oxygen atoms (Figure 8c) 


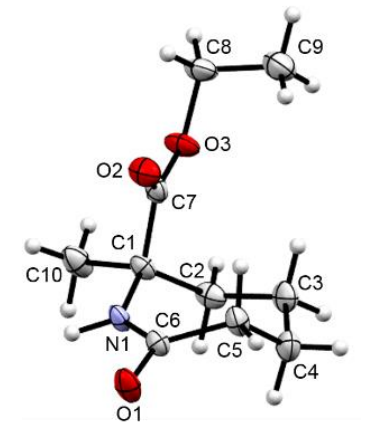

a)

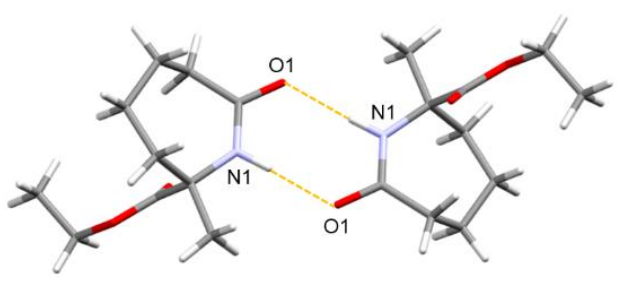

b)

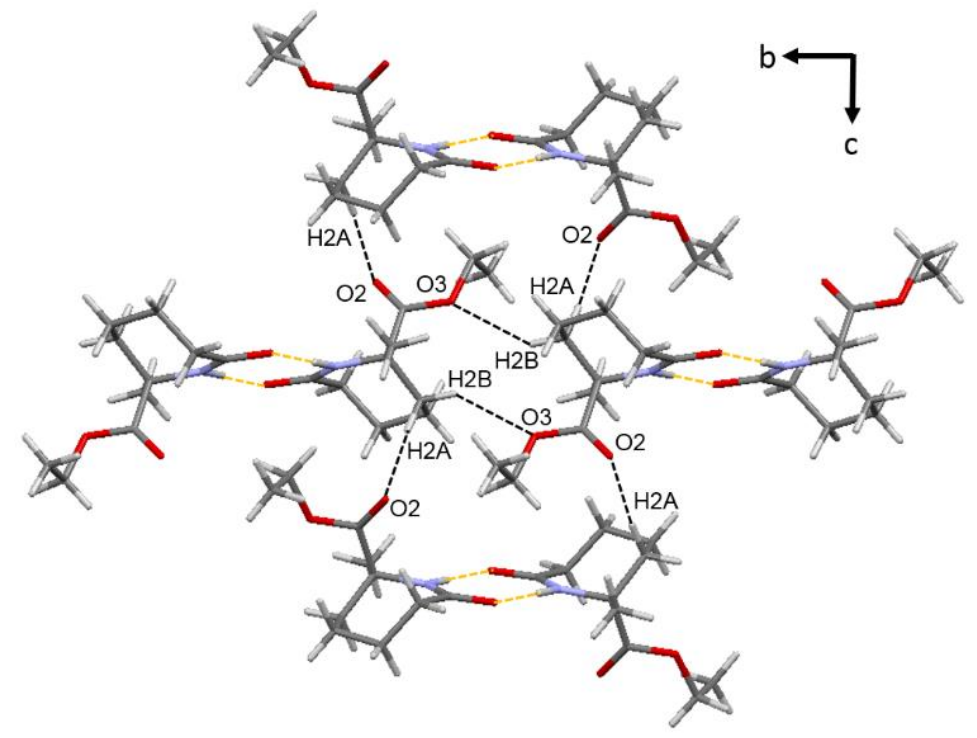

c)

Figure 8. a) Molecular structure of 5. b) Formation of displaced $R_{2}^{2}(8)$ dimers. c) Packing diagram of 5 featuring a combination of $\mathrm{NH} \cdots \mathrm{O}$ and $\mathrm{CH} \cdots \mathrm{O}$ hydrogen bonds

Enantholactams 6-8. All title lactams have been synthesized in a symmetric synthesis, i.e. they occur as racemates in solution. In most cases this leads to the formation of racemic crystals. However, for enantholactams $\mathbf{6}$ and $\mathbf{8}$ we observed the formation of conglomerates.

The overall conformation of enantholactam methyl ester $\mathbf{6}$ is rather close to the one of the parent enantholactam (CSD code: ENANOL ${ }^{68}$ ) as demonstrated by the similar torsions angles. The ester pendant was found in an equatorial position (Figure 9a). In general, for (enantho)lactam derivatives two hydrogen bonding patterns can be found in the literature: $\mathrm{R}_{2}^{2}(8)$ amide dimers ${ }^{69,70}$ and $\mathrm{C}(4)$ chains. ${ }^{71}$ However, in case of methyl ester $\mathbf{6}$ we found a third possible variation. The amide hydrogen is engaged in a quite weak $\mathrm{N}-\mathrm{H} \cdots \mathrm{O}$ hydrogen bond with the methoxy oxygen of the ester moiety (Figure 9b). This is rather unexpected since OMe oxygens are usually considered weaker acceptors than carbonyl oxygens, of which two can be found in the molecule. The amide carbonyl is engaged in a trifurcated $\mathrm{C}-\mathrm{H} \cdots \mathrm{O}$ contact $(\mathrm{C} 1 \cdots \mathrm{O} 1$, $\mathrm{C} 2 \cdots \mathrm{O} 1, \mathrm{C} 6 \cdots \mathrm{O} 1)$, whereas the ester carbonyl is involved in a bifurcated one $(\mathrm{C} 6 \cdots \mathrm{O} 2$, $\mathrm{C} 9 \cdots \mathrm{O} 2$ ). The donor-acceptor lengths of the trifurcated contact (four-center contact) found in 6 are shorter and the respective DHA angles much larger than for related systems. ${ }^{72-74}$ The overall packing can be described as a combination of two $\mathrm{R}_{2}^{2}(8) \mathrm{N}-\mathrm{H} \cdots \mathrm{O} / \mathrm{C}-\mathrm{H} \cdots \mathrm{O}=\mathrm{C}$ heterodimers. 


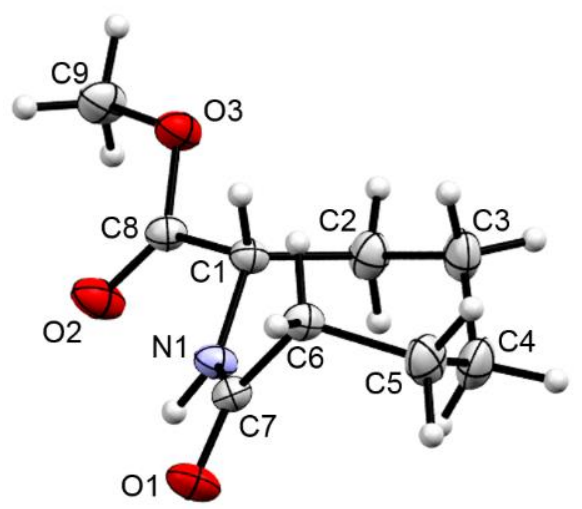

a)

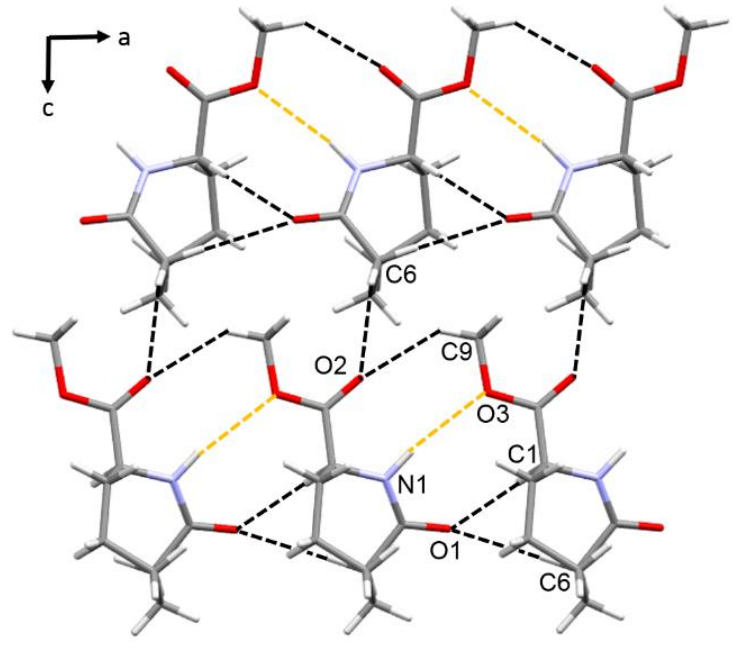

b)

Figure 9. a) Molecular structure of methylester 6. b) The combination of discreet $\mathrm{NH} \cdots \mathrm{O}$ hydrogen bonds and a series of $\mathrm{CH} \cdots \mathrm{O}$ contacts in $\mathbf{6}$ is in contrast to the packing of the other title lactams.

Title compound 7 has two molecules in the asymmetric unit representing the two enantiomers; the conformations of both differ only slightly. A comparison of ethyl ester 7 to the parent lactam and methyl ester $\mathbf{6}$ shows distinct variations in their respective conformations with a difference in torsion angles of about $15-20^{\circ}$. Moreover, the amide region is no longer coplanar as in ENANOL, though develops dihedral angles of -13.7(2) ${ }^{\circ}$ and 14.7(2) ${ }^{\circ}$, respectively. The COOEt unit is in an equatorial position for both molecules of the asymmetric unit (Figure 10a). As observed for the parent lactam the amide units of $\mathbf{7}$ are engaged in chains of strong $\mathrm{N}-\mathrm{H} \cdots \mathrm{O}$ hydrogen bonds best described with a $\mathrm{C}(4)$ graph descriptor, which is usually more typical for trans amides. ${ }^{75}$ By way of interest the DHA angle is much lower than observed for the unsubstituted enantholactam. In the overall packing of 7 the $\mathrm{N}-\mathrm{H} \cdots \mathrm{O}$ chains are interconnected by a series of weaker $\mathrm{C}-\mathrm{H} \cdots \mathrm{O}$ contacts. This includes a bifurcated contact $(\mathrm{C} 11 \cdots \mathrm{O} 2, \mathrm{C} 16 \cdots \mathrm{O} 2)$, an $\mathrm{R}_{2}^{2}(6)$ dimerization involving two ester groups (C9 $\left.\cdots \mathrm{O} 6, \mathrm{C} 19 \cdots \mathrm{O} 3\right)$

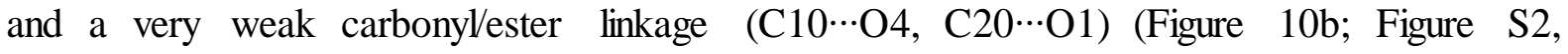
Supporting Information). 


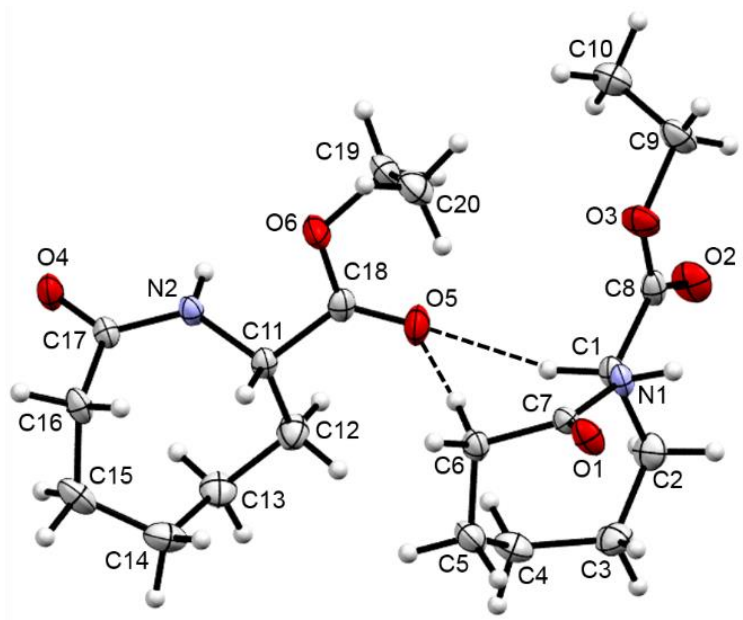

a)

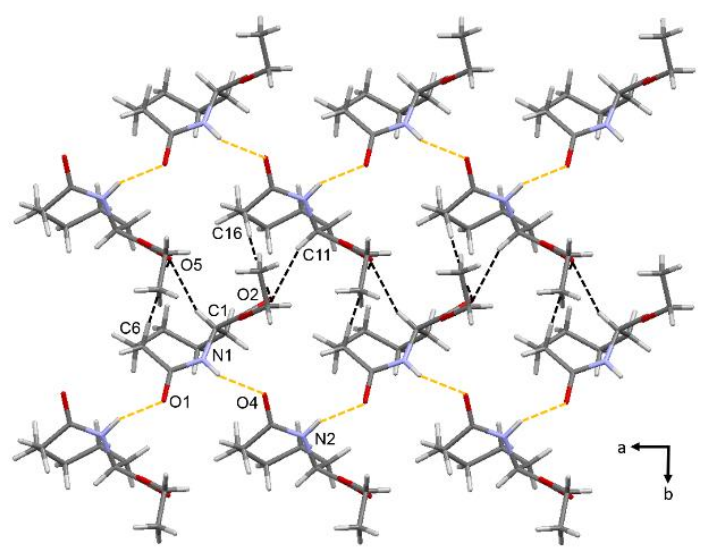

b)

Figure 10. a) Molecular structure of 7. b) Packing diagram of 7 featuring a combination of $\mathrm{NH}^{\cdots} \mathrm{O}$ hydrogen bonds and $\mathrm{CH}^{\cdots} \mathrm{O}$ contacts .

The introduction of the Boc group to enantholactam 7 does not change the equatorial position of the COOEt unit in title compound $\mathbf{8}$ unlike as observed for the smaller lactams. Though, the dihedral angle of the amide region increases to $-27.9(3)^{\circ}$; the conformational changes in the rest of molecule are less pronounced (Figure $11 \mathrm{a} / \mathrm{b}$ ). Due to the lack of strong $\mathrm{H}$ bond donors the non-covalent interactions in the packing is reliant on a series of $\mathrm{C}-\mathrm{H} \cdots \mathrm{O}$ contacts (Figure 11c). 


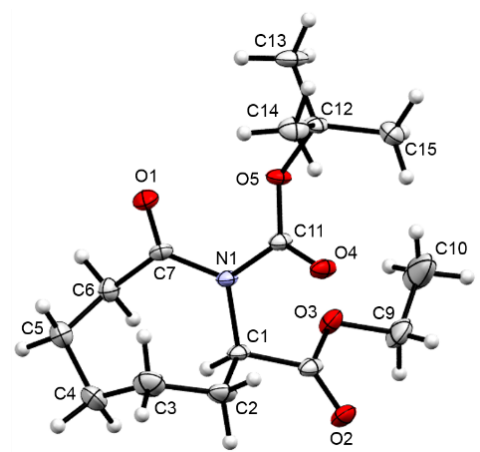

a)

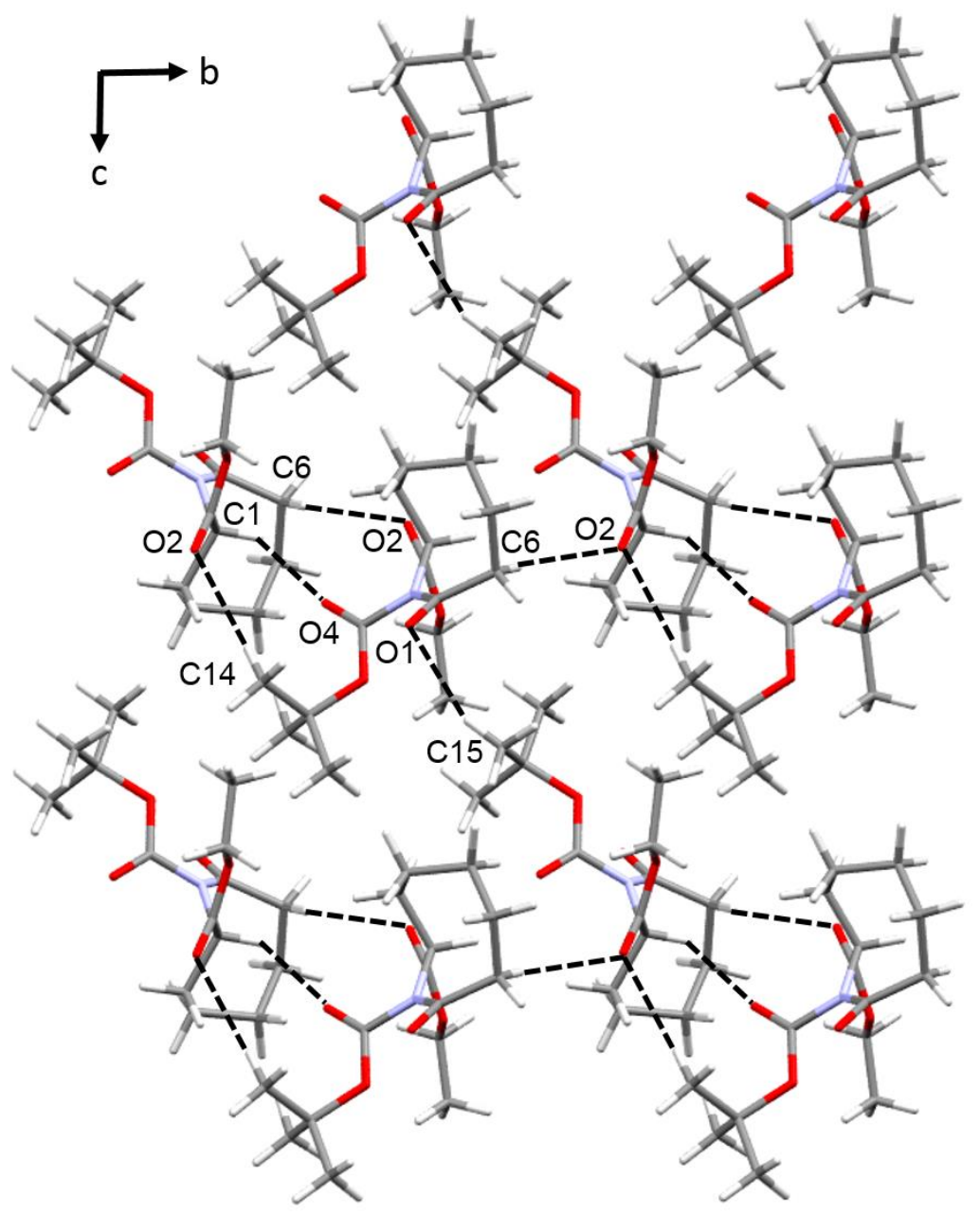

c)

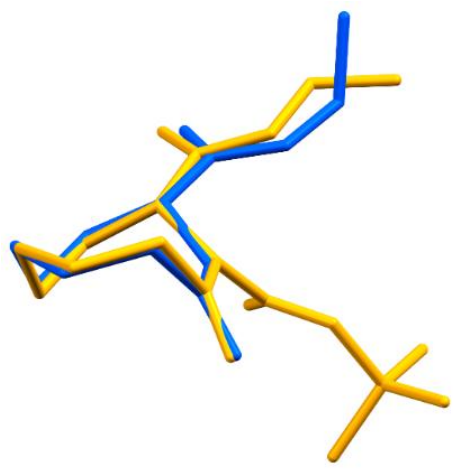

b) 

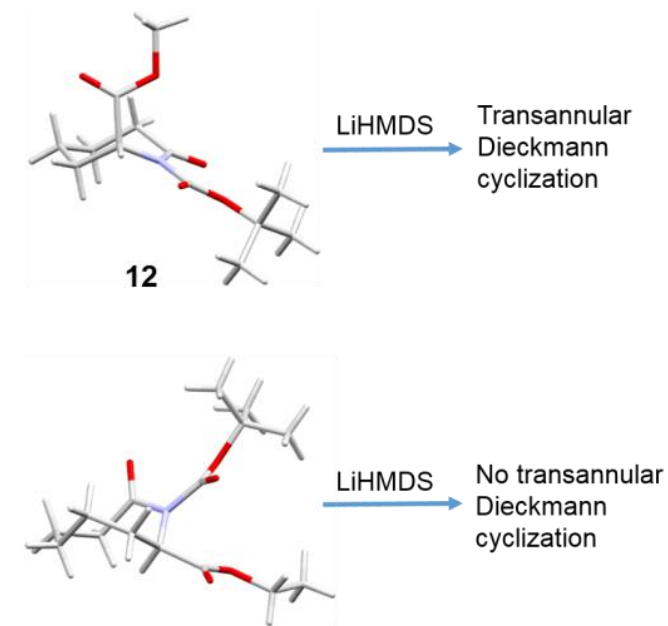

8

Figure 12. In comparis on to caprolactam ester 12 enantholactam ester $\mathbf{8}$ does not undergo a transannular Dieckmann cyclization reaction leading to a bicyclic system (cf. Figure 3).

Comparison of $\mathbf{N}_{\boldsymbol{\alpha}}$ carboxylated lactams. In order to put our findings in context to the literature, we analyzed published X-ray structures of related lactam acids and respective esters featuring a $\operatorname{COOR}\left(\mathrm{R}=\mathrm{H}\right.$, alkyl) in the $\mathrm{N}_{\alpha}$ position (Figure 13). A comprehensive structural analysis can be found in the Supplementary Information (Table S3-S7, Supporting Information).<smiles>O=C1CC(C(=O)O)N1</smiles>

PELJUM $^{76}$<smiles>CCOC(=O)N1C(=O)CCC1C(=O)OCc1ccccc1</smiles>

CEVBUC $^{8}$<smiles>O=C1CCCCC(C(=O)O)N1</smiles><smiles>CC(=O)C1CCCCC(=O)N1</smiles>

BOLHER $^{49}$<smiles>CCOC(=O)C1CCC(=O)N1</smiles>
$\mathrm{ABOQOA}^{78}$<smiles>CCCCN1C(=O)CCCC1C(=O)O</smiles>

LOQCOL $^{64}$<smiles>CC(=O)C1CCC=CC(=O)N1</smiles>

BOLJIX $^{49}$<smiles>N#[13C]N1C(=O)CCC1C(=O)O</smiles>

YAYM AO $^{79}$<smiles>CCCN1C(=O)CCCC1C(=O)O</smiles>

LOQCUR $^{64}$<smiles>CC(=O)OC(=O)C1CCCCC(=O)N1C(=O)c1ccccc1</smiles>

BOLHOB $^{49}(\mathbf{1 2})$ (poly morph I)<smiles>CCOC(=O)C1CCCC(=O)N1C(=O)c1ccccc1</smiles>

BAKYOC $^{82}$<smiles>CCOC(=O)C1CCC(=O)N1[10CH2]O</smiles>

YEKQOX $^{80}$<smiles>CC(=O)OC(=O)C1CCCCC(=O)N1C(=O)c1ccccc1</smiles>

BOLHOB $01^{19}(\mathbf{1 2})$ (poly morph II)

Figure 13. Reference compounds and their CSD refcodes. 
Butyrolactams. The envelope conformation of the butyrolactams discussed herein varies for different molecules, which is demonstrated by the broad range of deviation of carbon atom $\mathrm{C} 2$ from the mean amide plane (7.4-28.4 ${ }^{\circ}$ ). For the free acid and the difluoroethyl ester the carboxyl pendant prefers an equatorial position, for larger esters and $N$-substituted butyrolactams (Bn, Boc) it occupies an axial position. The butyrolactams with smaller ester residues were found to crystallize as $\mathrm{R}_{2}^{2}(8)$ amide dimers, those with larger ester residues as $\mathrm{C}(4)$ chains. Worth noting, esters of pyroglutamic acid have smaller Kitaigorodskii Packing Indeces (KPIs) than the free acid (72.6\%) and the respective parent lactam (71.8\%).

Valerolactams. The ethyl ester moiety of valerolactam takes an equatorial position, whereas in the free acid and in $\mathrm{N}$-derivatized (aryl, heteroaryl, Boc) acids and esters the carboxylate is clearly axial. The highest KPI is observed for the methylester and free acid (both $73.5 \%$ ). The free valerolactam and the methyl ester is engaged in $\mathrm{R}_{2}^{2}(8)$ amide dimers; the free acids are engaged in $\mathrm{C}(7)$ chains between amide carbonyl and $\mathrm{OH}$ group of the acid function.

Caprolactams. In the series of caprolactam carboxylates only the methyl ester and the acid were found as equatorial conformers; desaturation, second $\mathrm{N}_{\alpha}$ substitution and $N$-derivatization lead to axial ester units. The highest KPI has been found for the methylester (72.4\%). Accept for the acid all other caprolactams studied here - all of them are small esters - form $\mathrm{R}_{2}^{2}(8)$ dimers.

Enantholactams. Neither different ester residues (Me, Et) nor $N$-Boc-protection nor different packing modes seem to influence or change the equatorial COOR position. In comparison to the other lactams, the enantholactam esters have very similar torsion angles [149.11(4)-154.6(2) $\left.{ }^{\circ}\right]$, though their amide regions loose co-planarity with increasingly sized ester residues. The parent lactam and the ethyl ester form C(4) amide chains; for the methyl ester we were able to describe an alternative packing mode. The parent enantholactam has the highest KPI (70.7\%).

Full comparison of all lactams studied. It is worth noting that none of the lactams studied by X-ray diffraction in this paper contain solvents molecules. One possible explanation is the rather high degree of amide self-aggregation in solution, ${ }^{83}$ preventing strong interactions of the lactam with solvent molecules. The lengths of the amide bonds in the diverse ester derivatives only vary slightly (1.31-1.35 $\AA$ ) - indifferently from ring size or carboxy substituent. The only exceptions are the $N$-Boc lactams (imides) with 'amide bonds' of 1.39 to $1.42 \AA$ (Figure 14). The largest deviation from the parent lactam to ester is observed for the two Boc-caprolactam polymorphs of $12(6.14 \%$ / $6.68 \%)$.

The longer amide bond in $N$-Boc protected amides may have influence on the synthetic usability of the respective compounds. While the lactam ester BOLHER (Figure 12)-featuring an amide bond length of $1.347 \AA$ - can be rather easily transferred into the free lactam acid using $\mathrm{LiOH}$ in $\mathrm{THF} / \mathrm{H}_{2} \mathrm{O},{ }^{49}$ the longer amide bond in $\mathbf{1 2}$ may give rise to a hydrolytic ring opening under the same conditions (Scheme 1). (Details on the X-ray structure of the resulting diacid are given in the Supporting Information.) However, structural and hydrolytic studies for the unsubstituted parent lactams have shown, that not differences in the amide bond length are responsible for their varying hydrolytic behaviour. ${ }^{11,12}$ In fact, the formation of the tetrahedral intermediate - connected to the overall conformation of the lactam and potential substituents was shown to be rate-determining not so much the fission of the $\mathrm{C}-\mathrm{N}$ bond. So it cannot be ruled out that also the axial or equatorial position of the $\mathrm{N}_{\alpha}$ substituent has on influence on the rate of lactam hydrolysis. 


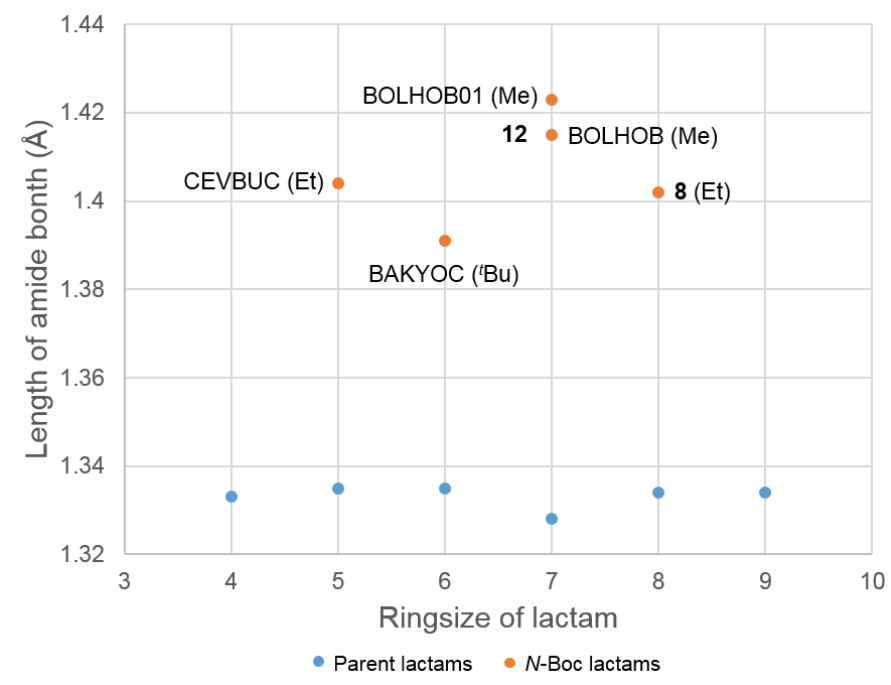

Figure 14. Comparis on of the amide bond lengths in $N$-Boc protected esters of different ring sizes (orange) and the respective parent lactams (blue). (CSD codes and the alkyl residues of the esters are shown.)

In the following we studied the influence of $\mathrm{N}_{\alpha}$ carboxyl lactams substitution pattern on the position of COOR unit. There seems to be a tendency, that for ring sizes 5-8, smaller esters $\left(\mathrm{Me}, \mathrm{Et}, \mathrm{Et}(\mathrm{F})_{2}\right)$ and the respective acids prefer an equatorial position (exception: valerolactam acid 4); larger ester $\left({ }^{i} \mathrm{Pr},{ }^{t} \mathrm{Bu}\right)$ were found to occupy axial sites. For ring sizes $5-7$ the $N$ substitution leads an axial arrangement the COOR pendant, as also observed for desaturation and $\mathrm{N}_{\alpha}$ methylation (for caprolactams). For all enantholactams studied the ester moiety occupied an equatorial position (Table 1).

Table 1. Influence of the substitution pattern of $\mathrm{N}_{\alpha}$ carboxyl lactams on the position of the COOR residue

\begin{tabular}{|c|c|c|c|c|}
\hline & 5 & 6 & 7 & 8 \\
\hline 0 & $\begin{array}{c}\mathrm{R}^{1}=\mathrm{H}, \mathrm{R}^{2}=\mathrm{H} \\
\mathrm{R}^{1}=\mathrm{Et}(\mathrm{F})_{2}, \mathrm{R}^{2}=\mathrm{H}\end{array}$ & $\mathrm{R}^{1}=\mathrm{Me}, \mathrm{R}^{2}=\mathrm{H}$ & $\begin{array}{c}\mathrm{R}^{1}=\mathrm{H}, \mathrm{R}^{2}=\mathrm{H} \\
\mathrm{R}^{1}=\mathrm{Me}, \mathrm{R}^{2}=\mathrm{H}\end{array}$ & $\begin{array}{c}\mathrm{R}^{1}=\mathrm{Me}, \mathrm{R}^{2}=\mathrm{H} \\
\mathrm{R}^{1}=\mathrm{Et}, \mathrm{R}^{2}=\mathrm{H} \\
\mathrm{R}^{1}=\mathrm{Et}, \mathrm{R}^{2}=\mathrm{Boc}\end{array}$ \\
\hline
\end{tabular}

\begin{tabular}{|c|c|c|c|c|}
\hline & 5 & 6 & 7 & 8 \\
\hline${ }_{0}^{-N}$ & $\begin{array}{c}\mathrm{R}^{1}=i \operatorname{Pr}, \mathrm{R}^{2}=\mathrm{H} \\
\mathrm{R}^{1}==^{t} \mathrm{Bu}, \mathrm{R}^{2}=\mathrm{H} \\
\mathrm{R}^{1}=\mathrm{H}, \mathrm{R}^{2}=\mathrm{Bn}(4-\mathrm{OH}) \\
\mathrm{R}^{1}=\mathrm{Et}, \mathrm{R}^{2}=\mathrm{Bn}(2-\mathrm{OH}) \\
\mathrm{R}^{1}=\mathrm{Et}, \mathrm{R}^{2}=\mathrm{Boc}\end{array}$ & $\begin{array}{c}\mathrm{R}^{1}=\mathrm{H}, \mathrm{R}^{2}=\mathrm{H} \\
\mathrm{R}^{1}=\mathrm{H}, \mathrm{R}^{2}=\mathrm{Bn} \\
\mathrm{R}^{1}=\mathrm{H}, \mathrm{R}^{2}=\text { thiophen }-2-\mathrm{yl} \\
\mathrm{R}^{1}=\mathrm{H}, \mathrm{R}^{2}=\text { thiophen }-3-\mathrm{yl} \\
\mathrm{R}^{1}={ }^{t} \mathrm{Bu}, \mathrm{R}^{2}=\mathrm{Boc}\end{array}$ & $\begin{array}{c}\mathrm{R}^{1}=\mathrm{Me}, \mathrm{R}^{2}=\mathrm{H} \\
\text { (monodesaturated) } \\
\mathrm{R}^{1}=\mathrm{Et}, \mathrm{R}^{2}=\mathrm{H} \\
\left(\mathrm{N}_{\alpha} \text { methylated) }\right. \\
\mathrm{R}^{1}=\mathrm{Me}, \mathrm{R}^{2}=\mathrm{Boc}\end{array}$ & --- \\
\hline
\end{tabular}

Also with respect to the hydrogen bonding systems we want to hypothesize that at least medium-sized free lactams (ring size 5-7) and small esters (Me, Et, $\mathrm{Et}(\mathrm{F})_{2},{ }^{i} \mathrm{Pr}$ ) will form $\mathrm{R}_{2}^{2}(8)$ amide dimers. Larger esters and enantholactam esters prefer $\mathrm{C}(4)$ chains. Such a switch from amide dimers to chains has already been observed for the parent lactams. ${ }^{11}$ The enantholactam methyl ester (6) should be seen as an exception in conjunction with the sizes of the lactam ring and the ester. 
For all lactam acids discussed here we found $\mathrm{O}-\mathrm{H} \cdots \mathrm{O}$ chains involving the hydroxyl group of the acid and the amide carbonyl; $\mathrm{C}(7)$ has been found as a common graph-set motif. For lactam acids featuring free $\mathrm{NH}$ functions, additional $\mathrm{C}=\mathrm{O} \cdots \mathrm{HN}$ hydrogen bonds lead to the cyclic motifs $\mathrm{R}_{3}^{3}(13)$ (ring size: 4; PELJUM), $\mathrm{R}_{2}^{2}(10)$ (ring size: 5; PYRGLU01) or $\mathrm{R}_{2}^{2}(8)$ motifs (ring size: 6; 4) (Figure 15). The respective caprolactam acid is an exception: here the molecules are arranged $\mathrm{R}_{2}^{2}(8)$ acid-amide heterodimers, which are typically only observed for amide/carboxylic acid co-crystals. ${ }^{84,85}$

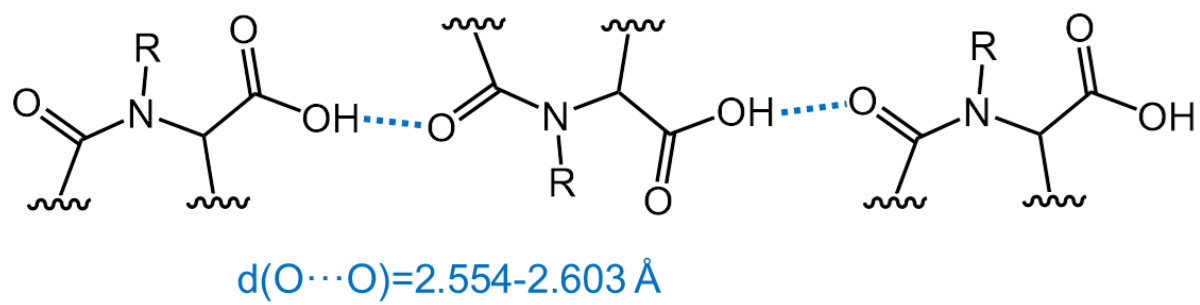

Figure 15. General hydrogen bonding motif found for $\mathrm{N}_{\alpha}$ carboxylactams (except for the respective caprolactam). Depending on the nature of $\mathrm{R}$, the $\mathrm{C}(7)$ chains are further interconnected: $\mathrm{R} \neq \mathrm{H}$ : no other strong hydrogen bonds; $\mathrm{R}=\mathrm{H}$ : further interactions via $\mathrm{N}-\mathrm{H} \cdots \mathrm{O}$ bonds.

\section{CONCLUSION}

In this paper we presented a series of $\mathrm{N}_{\alpha}$ substituted lactams esters and acids with respect to their overall conformation and hydrogen bonding pattern. In total, eight lactams have been synthesized and studied. In addition to the two literature-known amide packing motifs, i.e. $\mathrm{R}_{2}^{2}(8)$ amide dimer and $\mathrm{C}(4)$ amide chain, a third graph-set was found: $\mathrm{R}_{2}^{2}(8) \mathrm{N}-\mathrm{H} \cdots \mathrm{O} / \mathrm{C}-$ $\mathrm{H} \cdots \mathrm{O}=\mathrm{C}$ heterodimers. Additionally, $\mathrm{C}(7) \mathrm{O}-\mathrm{H} \cdots \mathrm{O}$ chains has been pinpointed as a typical graph-set motif for the lactam acids. With respect to the overall packing of the lactam ester it can be stated that it is rather rich in $\mathrm{C}-\mathrm{H} \cdots \mathrm{O}$ contacts. In most title compounds the slightly acidic carbon atom $\mathrm{C} 1$ is engaged in such contacts ranging from $3.226(3) \AA$ (8) to 3.440 (2) $\AA$ (2). This correlates with the importance of $\mathrm{C}_{\alpha}-\mathrm{H} \cdots \mathrm{O}$ contacts for the stability of protein structures. ${ }^{86}$

For comparison reasons, we also included a number of already published lactam esters and acids in our considerations. In general, it can be stated that none of the lactams' X-ray structures contain solvents molecules. To our surprise, the length of the amide bonds does not seem to be majorly influenced by different substituents unless the electron withdrawing $N$-Boc-protection group is introduced. We also found a higher susceptibility towards hydrolytic ring opening, which may go in conjunction with the elongated amide bond. In general, $\mathrm{N}_{\alpha}$ ester moieties have a preference to equatorial occupation for smaller ester as well as their free acids and axial occupation for larger ones. In the same way $N$-substitution leads to an axial arrangement the COOR pendant for ring sizes 5-7; in all enantholactam derivatives studied the ester units occupy equatorial positions. With regard to the crystal packing small esters of the mediumsized lactams seem to prefer the formation of $\mathrm{R}_{2}^{2}(8)$ amide dimers whereas larger esters and enantholactams form $\mathrm{C}(4)$ amide chains. In our opinion the formation of $\mathrm{R}_{2}^{2}(8) \mathrm{N}-\mathrm{H} \cdots \mathrm{O} / \mathrm{C}-$ $\mathrm{H} \cdots \mathrm{O}=\mathrm{C}$ heterodimers in $\mathbf{6}$ should be considered as exemption in lactams. We will test out this principle in further experiments in order to establish if the exception proves the rule or if $\mathrm{N}$ $\mathrm{H} \cdots \mathrm{O} / \mathrm{C}-\mathrm{H} \cdots \mathrm{O}=\mathrm{C}$ heterodimers are recurrent synthons in lactam structures. 


\section{ASSOCIATED CONTENT}

\section{Supporting Information}

X-ray crystallographic data files (CIF) for 1-8 and 13. Selected details of the data collection; table of distances and angles of inter- and intramolecular contacts and additional figures and tables underlining the structure description. ${ }^{1} \mathrm{H}$ and ${ }^{13} \mathrm{C}$ NMR spectra of compounds 1-8 and 13. The Supporting Information is available free of charge on the ACS Publications website at DOI: $\mathrm{xxx}$

\section{AUTHOR INFORMATION}

\section{Corresponding Author}

* Corresponding author. Tel.: +44 (0)1522 837396.

E-mail address: tgruber@lincoln.ac.uk (T. Gruber).

\section{Notes}

The authors declare no competing financial interest.

\section{ACKNOWLEDGMENTS}

We gratefully acknowledge financial support from the Royal Society of Chemistry (RF196355) and the School of Pharmacy, University of Lincoln.

\section{REFERENCES}

(1) Puffr, R.; Kubanek, V. Lactam-based Polyamides, CRC Press: Boca Raton, USA, 1991.

(2) Ritz, J.; Fuchs, H.; Kieczka, H.; Moran, W. C. "Caprolactam”, In: Ullmann's Encyclopedia of Industrial Chemistry, Wiley-VCH: Weinheim, Germany, 2005.

(3) Zheng, J.-F.; Hu, X.-N.; Xu, Z.; Cai, D.-C.; Shen, T.-L.; Huang, P.-Q. Substrate-Controlled Chemoselective Reactions of Isocyanoacetates with Amides and Lactams. J. Org. Chem., 2017, 82, 9693-9703.

(4) Bengtsson, C.; Wetzel, A.; Bergman, J.; Brånalt, J. Unexpected Retroaldol-Aldol Reaction during $O$-Alkylation of Hydroxylated Vince Lactam Derivatives. J. Org. Chem. 2016, 81, 708714.

(5) Kim, K.; Hong, S. H. Iridium-Catalyzed Single-Step $N$-Substituted Lactam Synthesis from Lactones and Amines. J. Org. Chem. 2015, 80, 4152-4156.

(6) Szcześniak, P.; Maziarz, E.; Stecko, S.; Furman, B. Synthesis of Polyhydroxylated Piperidine and Pyrrolidine Peptidomimetics via One-Pot Sequential Lactam Reduction/JoulliéUgi Reaction. J. Org. Chem. 2015, 80, 3621-3633.

(7) Janecki, T. (Ed.) Natural Lactones and Lactams: Synthesis, Occurrence and Biological Activity, Wiley VCH: Weinheim, Germany, 2013. 
(8) Bulman Page, B. C.; Goodyear, R. L.; Horton, A. E.; Chan, Y.; Karim, R.; O’Connell, M. A.; Hamilton, C.; Slawin, A. M. Z.; Buckley, B. R.; Allin, S. M. Formal Total Synthesis of (+)C9-Deoxyomuralide from L-Leucine Using a Double Sacrificial Chirality Transfer Approach. J. Org. Chem. 2017, 82, 12209-12223.

(9) Morin, R. B.; Gorman, M. (Eds.) The Biology of $\beta$-Lactam Antibiotics, Academic Press: Cambridge, USA, 2014.

(10) Montaudo, G.; Caccamese, S.; Librando, V.; Recca, A. Structural analysis by lanthanide shift reagents: IV. Conformation of the amide group as a function of the ring size in lactams. J. Mol. Struct. 1975, 27, 303-308.

(11) Weck, C.; Nauha, E.; Gruber, T. Missing Link in the Homologous Series of Lactams: The X-ray Structure of Valerolactam. Cryst. Growth Des. 2018, 18, 7248-7253.

(12) Imming, P.; Klar, B.; Dix, D. Hydrolytic Stability versus Ring Size in Lactams: Implications for the Development of Lactam Antibiotics and Other Serine Protease Inhibitors. J. Med. Chem. 2000, 43, 4328-4331.

(13) Abraham, R. J.; Filippi, M.; Petrillo, G.; Piaggio, P.; Vladiskovic, C.; Sancassan, F. A theoretical and NMR lanthanide-induced shift (LIS) investigation of the conformations of lactams. Magn. Reson. Chem. 2017, 55, 1059-1072.

(14) Goudedranche, S.; Besnard, C.; Egger, L.; Lacour, J. Synthesis of Pyrrolidines and Pyrrolizidines with $\alpha$-Pseudoquaternary Centers by Copper-Catalyzed Condensation of $\alpha$ Diazodicarbonyl Compounds and Aryl $\gamma$-Lactams. Angew. Chemie, Int. Ed. 2016, 55, 1377513779.

(15) Emel'yanenko, V. N.; Verevkin, S. P.; Turovtsev, V. V.; Orlov, Y. D. Enthalpies of formation of lactams. Russ. J. Phys. Chem. A 2013, 87, 901-905.

(16) Emel'yanenko, V. N.; Turovtsev, V. V.; Orlov, Y. D. Thermodynamic functions of lactams in the ideal gas state. Russ. J. Phys. Chem. A 2014, 88, 1472-1477.

(17) Lamotte, J.; Dive, G.; Ghuysen, J. M. Conformational analysis of $\beta$ and $\gamma$-lactam antibiotics. Eur. J. Med. Chem. 1991, 26, 43-50

(18) Cosentino, U.; Scolastico, C.; Moro, G.; Morosi, G.; Pitea, D. The influence of the calculation method on conformational analysis of pyrrolidin-2-one derivatives. J. Mol. Struct. 1989, 60, 199-212.

(19) Weck, C.; Obst, F.; Nauha, E.; Schofield, C. J.; Gruber, T. Synthesis of a bicyclic oxo- $\gamma-$ lactam from a simple caprolactam derivative. New J. Chem. 2017, 41, 9984-9989.

(20) Frese, A.; Sutton, P. W.; Turkenburg, J. P.; Grogan, G. Snapshots of the Catalytic Cycle of the Industrial Enzyme $\alpha$-Amino- $\varepsilon$-Caprolactam Racemase (ACLR) Observed Using X-ray Crystallography. ACS Catal. 2017, 7, 1045-1048. 
(21) Ryan, J. H.; Smith, J. A.; Hyland, C.; Meyer, A. G.; Williams, C. C.; Bissember, A. C.; Just, Seven-Membered Rings. J. Progr. Heterocycl. Chem. 2014, 26, 521-571.

(22) MacGregor, E. A. Telcagepant: A New Therapeutic Option for Acute Migraine. Clin. Med. Insights: Ther. 2011, 3, 301-314.

(23) Cuiban, F.; Bolocan, I.; Barbu, E. N-Substituted derivatives of $\varepsilon$-caprolactam and their thermal and chemical behavior. ARKIVOC 2002, 56-63.

(24) Parker, M. F.; Bronson, J. J.; Barten, D. M.; Corsa, J. A.; Du, W.; Felsenstein, K. M.; Guss, V. L.; Izzarelli, D.; Loo, A.; McElhone, K. E.; Marcin, L. R.; Padmanabha, R.; Pak, R.; Polson, C. T.; Toyn, J. H.; Varma, S.; Wang, J, Wong. V.; Zheng, M., Roberts, S. B. Aminocaprolactam derivatives as $\gamma$-secretase inhibitors. Bioorg. Med. Chem. Lett. 2007, 17, 57905795 .

(25) Knapp, S.; Nandan, S. R. Synthesis of capuramycin. J. Org. Chem. 1994, 59, 281-283.

(26) Stephens, T. C.; Lodi, M.; Steer, A. M.; Lin, Y.; Gill, M. T.; Unsworth, W. P. Synthesis of Cyclic Peptide Mimetics by the Successive Ring Expansion of Lactams. Chem.Eur. J. 2017, 23, 13314-13318.

(27) Molina, C. L.; Chow, C. P.; Shea, K. J. Type 2 Intramolecular N-Acylazo Diels-Alder Reaction: Regio- and Stereoselective Synthesis of Bridgehead Bicyclic 1,2-Diazines. J. Org. Chem. 2007, 72, 6816-6823.

(28) Bouazaoui, M.; Larrouy, M.; Martinez, J.; Cavelier, F. Efficient Synthesis of Nicotianamine and Non-Natural Analogues. Eur. J. Org. Chem. 2010, 34, 6609-6617.

(29) Dyer, J.; King, A.; Keeling, S.; Moloney, M. G. Pyrrolidinones derived from (S)pyroglutamic acid. Part 2. Conformationally constrained kainoid analogues. Perkin Trans 1 2000, 16, 2793-2804.

(30) Bourry, A.; Rigo, B.; Sanz, G.; Couturier, D. Studies on pyrrolidinones: Some attempts to improve the anticancer properties of methyl $n$-(3,4,4',5-tetramethoxybenzhydryl)pyroglutamate (HEI 81). J. Heterocycl. Chem. 2002, 39, 119-124.

(31) Rigo, B.; Lespagnol, C.; Pauly, M. Studies on pyrrolidinones. Synthesis of $N$-acylpyroglutamic esters with bactericide and fungicide properties. J. Heterocycl. Chem. 1988, 25, 4957.

(32) Gang, F.-L.; Zhu, F.; Li, X-T.; Wei, J.-L.; Wu, W.-J.; Zhang, J.-W. Synthesis and bioactivities evaluation of L-pyroglutamic acid analogues from natural product lead. Bioorg. Med. Chem. 2018, 26, 4644-4649.

(33) Bischoff, M.; Sippel, C.; Bracher, A.; Hausch, F. Stereoselective Construction of the 5Hydroxy Diazabicyclo[4.3.1]decane-2-one Scaffold, a Privileged Motif for FK506-Binding Proteins. Org. Lett. 2014, 16, 5254-5257.

(34) Claverie, C.; Ghinet, A.; Gautret, P.; Vuong, C.-T.; Rigo, B. The revisited synthesis of tert-butyl pyroglutamate derivatives. Tetrahedron 2013, 69, 6821-6825. 
(35) Hamed, R. B.; Henry, L.; Gomez-Castellanos, J. R.; Mecinovic, J.; Ducho, C.; Sorensen, J. L.; Claridge, T. D. W.; Schofield, C. J. Crotonase Catalysis Enables Flexible Production of Functionalized Prolines and Carbapenams. J. Am. Chem. Soc. 2012, 134, 471-479.

(36) Ibrahim, M. A.; Johnson, H. W. B.; Jeong, J. W.; Lewis, G. L.; Shi, X.; Noguchi, R.T .; Williams, M.; Leahy, J. W.; Nuss, J. M.; Woolfrey, J.; Banica, M.; Bentzien, F.; Chou, Y.-C.; Gibson, A; Heald, N.; Lamb, P.; Mattheakis, L.; Matthews, D.; Shipway, A.; Wu, X.; Zhang, W. T.; Zhou, S.; Shankar, G. Discovery of a Novel Class of Potent and Orally Bioavailable Sphingosine 1-Phosphate Receptor 1 Antagonists. J. Med. Chem. 2012, 55, 1368-1381.

(37) Gao, M.; Wang, M.; Glick-Wilson, B. E.; Meyer, J. A.; Peters, J. S.; Territo, P. R.; Green, M. A.; Hutchins, G. D.; Zarrinmayeh, H.; Zheng, Q.-H. Synthesis and preliminary biological evaluation of a novel P2X7R radioligand [18F]IUR-1601. Bioorg. Med. Chem. Lett. 2018, 28, 1603-1609.

(38) Kim, S.; Ko, H.; Lee, T.; Kim, D. Formal Synthesis of (-)-Perhydrohistrionicotoxin via Cyclic Amino Acid Ester-Enolate Claisen Rearrangement and Ring-Closing Metathesis. $J$. Org. Chem. 2005, 70, 5756-5759.

(39) Borja, M.; Brunner, F.; Bonet G. J; Olivares, P.; Sanz, Y.; Perez, R. Methods and compositions for improving plant health and/or yield. PCT Int. Appl., WO 2018167347 A2 20180920, 2018.

(40) Vincent, M.; Remond, G.; Portevin, B.; Herve, Y.; Lepagnol, J. Preparation of tripeptide analogs containing azepinone moiety as TRH agonists and pharmaceutical compositions containing them. Eur. Pat. Appl., EP 462884 A1 19911227, 1991.

(41) Masschelein, K. G. R.; Stevens, C. V.; Dieltiens, N.; Claeys, N. N. Exploiting the regioselectivity of pyroglutamate alkylations for the synthesis of 6-azabicyclo[3.2.1]octanes and 4-azabicyclo[3.3.0] octanes. Tetrahedron 2007, 63, 4712-4724.

(42) Dieltiens, N.; Stevens, C. V.; Masschelein, K. G. R.; Rammeloo, T. [1,2] Boc migration during pyroglutamate alkylations. Tetrahedron 2005, 61, 6749-6756.

(43) Koldobskii, G. I.; Tereshchenko, G. F.; Gerasimova, E. S.; Bagal, L. I. Uspekhi Khimii 1971, 40, 1790-1813.

(44) Wolff, H. The Schmidt Reaction. Org. React. 1946, 3, 307-336.

(45) Shneider, O. S.; Pisarevsky, E.; Fristrup, P. Szpilman, A. M. Oxidative Umpolung $\alpha-$ Alkylation of Ketones. Org. Lett. 2015, 17, 282-285.

(46) Overberger, C. G.; Shalati, M. D. Synthesis and resolution of substituted pipecolic acids. Eur. Polymer. J. 1983, 19, 1055-1065.

(47) Ikeda, S.; Shibuya, M.; Kanoh, N. Iwabuchi, Y. Synthetic Studies on Daphnicyclidin A: Enantiocontrolled Construction of the BCD Ring System. Org. Lett. 2009, 11, 1833-1836. 
(48) Darses, B.; Michaelides, I. N.; Sladojevich, F.; Ward, J. W.; Rzepa, P. R.; Dixon, D. J. Expedient Construction of the [7-5-5] All-Carbon Tricyclic Core of the Daphniphyllum Alkaloids Daphnilongeranin B and Daphniyunnine D. Org. Lett. 2012, 14, 1684-1687.

(49) Gruber, T.; Thompson, A. L.; Odell, B.; Bombicz, P.; Schofield, C. J. Conformational studies on substituted $\varepsilon$-caprolactams by X-ray crystallography and NMR spectroscopy. New J. Chem. 2014, 38, 5905-5917.

(50) Taschner, E.; Wasielewski, C.; Biernat, J. F. Neue Veresterungsmethoden in der Peptidchemie, IV. Darstellung von tert.-Butylestern $N$-acylierter Aminosäuren mit Hilfe von tert.-Butylacetat. Liebigs Ann. 1961, 646, 119-122.

(51) Besson, M.; Delbecq, F.; Gallezot, P.; Neto, S.; Pinel, C. Asymmetric Synthesis of 2Methyl Cyclohexane Carboxylic Acids by Heterogeneous Catalysis: Mechanistic Aspects. Chem. Eur. J. 2000, 6, 949-958.

(52) Davies, C. E.; Heightman, T. D.; Hermitage, S. A.; Moloney, M. G. Convenient preparations of racemic and enantiopure methyl 6-oxopipecolate. Synth. Comm. 1996, 26, 687696.

(53) Shostakovskii, M. F.; Rabinovich, M. S.; Preobrazhenskaya, E. V.; Zykova, G. N. Synthesis of precursors and fragments of antibiotics. I. $\alpha$-Aminoadipic acid. Zhurnal Obshchei Khimii 1960, 30, 67-71.

(54) Benati, L.; Nanni, D.; Sangiorgi, C.; Spagnolo, P. Radical Chain Reactions of $\alpha$-Azido- $\beta$ keto Esters with Tributyltin Hydride. A Novel Entry to Amides and Lactams through Regiospecific Nitrogen Insertion. J. Org. Chem. 1999, 64, 7836-7841.

(55) Blicke, F. F. 2-(1-methyl) polymethyleniminylmethyl benzhydryl ethers and preparation thereof. US $270819419550510,1955$.

(56) Barton, D. H. R.; Herve, Y. Potier, P.; Thierry, J. Synthesis of novel $\alpha$-amino-acids and derivatives using radical chemistry: synthesis of L- and D- $\alpha$-amino-adipic acids, L- $\alpha$. Tetrahedron 1987, 43, 4297-4308.

(57) Sheldrick, G. M. A short history of SHELX. Acta Crystallogr. 2008, A64, 112-122.

(58) Hübschle, C. B.; Sheldrick, G. M.; Dittrich, B. ShelXle: a Qt graphical user interface for SHELXL. J. Appl. Crystallogr. 2011, 44, 1281-1284.

(59) Yar, M.; Unthank, M. G.; McGarrigle, E. M.; Aggarwal, V. K. Remote Chiral Induction in Vinyl Sulfonium Salt-Mediated Ring Expansion of Hemiaminals into Epoxide-Fused Azepines. Chem. Asian J. 2011, 6, 372-375.

(60) He, W.; Griffiths, B. M.; Wang, W.; Wang, X. Diastereoselective synthesis and biological evaluation of enantiomerically pure tricyclic indolines. Org. Biomol. Chem. 2017, 15, 42414245 .

(61) Goddard, R.; Heinemann, O.; Kruger, C.; Magdo, I.; Mark, F.; Schaffner, K. A LowTemperature Phase of 2-Pyrrolidone. Acta Crystallogr. 1998, C54, 501-504. 
(62) Wagger, J.; Grdadolnik, S. G.; Groselj, U.; Meden, A.; Stanovnik, B.; Svete, J. Chiral solvating properties of (S)-1-benzyl-6-methylpiperazine-2,5-dione. Tetrahedron: Asym. 2007, $18,464-475$

(63) Sivý, J.; Vrábel, V.; Marchalín, Š.; Šafár̆, P. Novel Route for Synthesis of (S)-1-Benzyl-6oxopiperidine-2-carboxylic Acid and its Crystal Structure. Asian J. Chem. 2015, 27, 2635-2638.

(64) Vrábel, V.; Sivý, J.; Šafár̆, P.; Marchalín, Š. Electronic structure, novel synthesis, and O$\mathrm{H}$...O and $\mathrm{C}-\mathrm{H}$...O interactions in two 6-oxopiperidine-2-carboxylic acid derivatives. Acta Crystallogr. 2014, C70, 817-822.

(65) Groenewald, F.; Dillen, J. Conformational analysis of caprolactam, cycloheptene and caprolactone. Struct. Chem. 2012, 23, 723-732.

(66) Favini, G. Conformational analysis of seven-membered cyclic systems. J. Mol. Struct. 1983, 93, 139-152.

(67) Winkler, F. K.; Dunitz, J. D. Medium-ring compounds. XIX. Caprolactam: structure refinement. Acta Crystallogr. 1975, B31, 268-269.

(68) Winkler, F. K.; Seiler, P. Enantholactam (7-heptanelactam), at 98 K. Acta Crystallogr. 1979, B35, 1920-1922.

(69) Liu, L.; Chen, Q.; Wu, Y.-D.; Li, C. 8-Endo versus 7-Exo Cyclization of $\alpha$-Carbamoyl Radicals. A Combination of Experimental and Theoretical Studies. J. Org. Chem. 2005, 70, 1539-1544.

(70) Blake, A. J.; Hollingworth, G. J.; Pattenden, G. Radical Mediated MacrocyclisationTransannulation Cascades leading to Ring-fused Lactones and Lactams. Synlett 1996, 643-644.

(71) Hu, T.; Shen, M.; Chen, Q.; Li, C. Pushing Radical Cyclization from Regioselective to Regiospecific: Cyclization of Amidyl Radicals Controlled by Vinylic Halogen Substitution. Org. Lett. 2006, 8, 2647-2650.

(72) Kavitha, C. N.; Jasinski, J. P.; Kaur, M.; Anderson, B. J.; Yathirajan, H. S. Crystal structure of 1-(3-chlorophenyl)-piperazin-1-ium picrate-picric acid (2/1). Acta Crystallogr. 2014, E70, o1210-o1211.

(73) Jasinski, J. P.; Butcher, R. J.; Mallesha, L.; Mohana, K. N.; Yathirajan, H. S.; Narayana, B. Crystal Structure of 3-Oxo-4-Aza-5-Alpha-Androstone-17 $\beta$-Tert Butyl Carboxamide with an $\mathrm{O} \cdots \mathrm{H}-(\mathrm{C}, \mathrm{N})$ Acceptor Four-Center Hydrogen Bond. J. Chem. Cryst. 2009, 39, 458-465.

(74) Padiyar, G. S.; Seshadri, T. P. Trifurcated (Four-Center) Hydrogen Bond in Solid State Crystal Structure of 5'-Amino-5'-deoxyadenosine p-Toluenesulfonate. Nucleosides \& Nucleotides 1996, 15, 857-865.

(75) Vasylyeva, V.; Nayak, S. K.; Terraneo, G.; Cavallo, G.; Metrangolo, P.; Resnati, G. Orthogonal halogen and hydrogen bonds involving a peptide bond model. CrystEngComm 2014, 16, 8102-8105. 
(76) Mora, A. J.; Brunelli, M.; Fitch, A. N.; Wright, J.; Baez, M. E.; Lopez-Carrasquero, F. Structures of $(S)$-(-)-4-oxo-2-azetidinecarboxylic acid and 3-azetidinecarboxylic acid from powder synchrotron diffraction data. Acta Crystallogr. 2006, B62, 606-611.

(77) Taira, Z.; Watson, W. H. The structure of a 1:1 mixed crystal of L-glutamic acid and Lpyroglutamic acid, $\mathrm{C}_{5} \mathrm{H}_{9} \mathrm{NO}_{4} . \mathrm{C}_{5} \mathrm{H}_{7} \mathrm{NO}_{3} . \mathrm{H}_{2} \mathrm{O}$, and a refinement of the structure of pyroglutamic acid, $\mathrm{C}_{5} \mathrm{H}_{7} \mathrm{NO}_{3}$. Acta Crystallogr. 1977, B33, 3823-3827.

(78) Mykhailiuk, P. K.; Kishko, I.; Kubyshkin, V.; Budisa, N.; Cossy, J. Selective ${ }^{19}$ F-Labeling of Functionalized Carboxylic Acids with Difluoromethyl Diazomethane $\left(\mathrm{CF}_{2} \mathrm{HCHN}_{2}\right)$. Chem. Eur. J. 2017, 23, 13279-13283.

(79) Chen, J.; Sheng, T.; Hu, S.; Xiang, S.; Fu, R.; Zhu, Q.; Wu, X. Homochiral coordination polymers constructed from aminocarboxylate derivates: Effect of bipyridine on the amidation reaction. J. Solid State Chem. 2012, 192, 255-262.

(80) Mulla, R. S.; Walden, M. T.; Yufit, D. S.; Desa, T.; Lurie-Luke, E.; Williams, J. A. G. Strategies for the synthesis of $\mathbf{H B G l}_{3}$, a glutamic acid derived ligand bearing phenolic and azacarboxylate donor groups at the nitrogen atom. Tetrahedron 2017, 73, 6410-6420.

(81) Rajalakshmi, P.; Srinivasan, N.; Krishnakumar, R. V.; Razak, I. A.; Rosli, M. M. NButoxycarbonyl-5-oxo-L-proline ethyl ester. Acta Crystallogr. 2013, E69, o567-o568.

(82) Marin, J.; Didierjean, C.; Aubry, A.; Briand, J.-P.; Guichard, G. Diastereoselective Hydroxylation of 6-Substituted Piperidin-2-ones. An Efficient Synthesis of $(2 S, 5 R)-5$ Hydroxylysine and Related $\alpha$-Amino Acids. J. Org. Chem. 2002, 67, 8440-8449.

(83) Montaudo, G.; Caccamese, S.; Recca, A. Self-association in lactams as a function of the ring size. J. Phys. Chem. 1975, 79, 1554-1557.

(84) Saha, S.; Desiraju, G. R. Acid $\cdots$ Amide Supramolecular Synthon in Cocrystals: From Spectroscopic Detection to Property Engineering. J. Am. Chem. Soc. 2018, 140, 6361-6373.

(85) Moragues-Bartolome, A. M.; Jones, W.; Cruz-Cabeza, A. J. Synthon preferences in cocrystals of cis-carboxamides:carboxylic acids. CrystEngComm, 2012, 14, 2552-2559.

(86) Mottamal, M.; Lazaridis, T. The Contribution of $\mathrm{C}_{\alpha}-\mathrm{H} \cdots \mathrm{O}$ Hydrogen Bonds to Membrane Protein Stability Depends on the Position of the Amide. Biochemistry 2005, 44, $1607-1613$. 
For Table of Contents Use Only

'Does the exception prove the rule? - A

comparative study of supramolecular synthons in a series of lactam esters"

C. Weck, E. Nauha, T. Gruber*

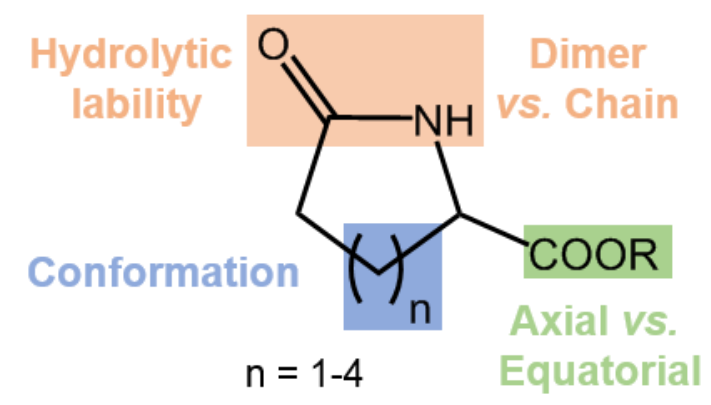

A series of simple $\mathrm{N}_{\alpha}$-substituted lactam esters and carboxylic acids is studied with respect to bond length, overall conformation and hydrogen bonding pattern. In addition to the two common amide packing motifs, i.e. the $\mathrm{R}_{2}^{2}(8)$ amide dimer $(\mathrm{NH} \cdots \mathrm{O} / \mathrm{NH} \cdots \mathrm{O})$ and the $\mathrm{C}(4)$ amide chain, a third graph-set was found: the $\mathrm{R}_{2}^{2}(8) \mathrm{NH} \cdots \mathrm{O} / \mathrm{CH} \cdots \mathrm{O}=\mathrm{C}$ heterodimer. 